OPEN ACCESS

Edited by:

Mashura Shammi,

Jahangirnagar University, Bangladesh

Reviewed by:

Anirban Akhand,

Port and Airport Research Institute

(PARI), Japan

Abhijit Chatterjee,

Bose Institute, India

*Correspondence:

Sandip Kumar Mukhopadhyay

skm.caluniv@gmail.com

Specialty section:

This article was submitted to

Biogeoscience,

a section of the journal

Frontiers in Earth Science

Received: 01 November 2021

Accepted: 05 January 2022

Published: 18 February 2022

Citation:

Acharya A, Sanyal P, Paul M,

Gupta VK, Bakshi S and

Mukhopadhyay SK (2022) Distribution and Dynamics of Radiatively Active Gas (RAG) Emissions From Major

Estuaries of the Sundarbans

Mangrove, India.

Front. Earth Sci. 10:806897.

doi: 10.3389/feart.2022.806897

\section{Distribution and Dynamics of Radiatively Active Gas (RAG) Emissions From Major Estuaries of the Sundarbans Mangrove, India}

\author{
Avanti Acharya ${ }^{1}$, Prasun Sanyal ${ }^{1}$, Madhusudan Paul ${ }^{1}$, Vandana Kumari Gupta ${ }^{1}$, \\ Sneha Bakshi ${ }^{1}$ and Sandip Kumar Mukhopadhyay ${ }^{1,2 *}$ \\ ${ }^{1}$ Department of Marine Science, University of Calcutta, Kolkata, India, ${ }^{2}$ Ministry of Earth Sciences, Government of India, New \\ Delhi, India
}

The world's largest mangroves ecosystem, the Sundarbans, being highly productive and a place for extensive organic matter cycling, is considered to be the hotspot for biogeochemical studies in the tropical estuarine environment. Hence, the spatial and temporal dynamics of the biogenic gases $\left(\mathrm{CO}_{2}, \mathrm{CH}_{4}\right.$, and $\left.\mathrm{N}_{2} \mathrm{O}\right)$, also known as radiatively active gases, were measured in mangrove-dominated estuaries of the system. In addition to spatial and seasonal observation, three full tidal cycles were observed at one site. Results showed that the air/water gas saturations were widely distributed and highly variable along the stretch. The gas saturations showed varying responses to salinity and tidal fluctuations. This indicated that localized biogeochemical processes may be more influential than simple mixing and dilution processes in controlling the variability of these gases. The surface waters were always supersaturated with $\mathrm{CH}_{4}$ (Up to 13,133\%) relative to the atmosphere. However, $\mathrm{N}_{2} \mathrm{O}$ ranged from 8 to $1,286 \%$ and $\mathrm{CO}_{2}$ from 30 to $2075 \%$. $\mathrm{N}_{2} \mathrm{O}$ fluxes were $\sim 4.8$ times higher in the pre-monsoon than the post-monsoon. $\mathrm{CH}_{4}$ fluxes were 3.6 times higher in the pre-monsoon than both the monsoon and the postmonsoon. $\mathrm{CO}_{2}$ fluxes were 10 times higher in the monsoon than both the premonsoon and the post-monsoon. The seasonality in the gas saturation could be linked more to the availability of substrates than physicochemical parameters. Overall, air/water $\mathrm{CH}_{4}$ fluxes varied maximally $\left(0.4-18.4 \mu \mathrm{mol} \mathrm{m}^{-2} \mathrm{~d}^{-1}\right)$, followed by $\mathrm{CO}_{2}$ fluxes $\left(-0.6-10.9 \mathrm{mmol} \mathrm{m}^{-2} \mathrm{~d}^{-1}\right)$, and $\mathrm{N}_{2} \mathrm{O}$ fluxes varied the least of all $\left(-0.6-5.4 \mu \mathrm{mol} \mathrm{m}{ }^{-2}\right.$ $\mathrm{d}^{-1}$ ). Interestingly, $\mathrm{CH}_{4}$ and $\mathrm{N}_{2} \mathrm{O}$ fluxes were positively correlated to each other $(p<0.05)$, suggesting organic matter decomposition as the key factor in the production of these two gases. Finally, these water-air $\mathrm{CO}_{2}, \mathrm{CH}_{4}$, and $\mathrm{N}_{2} \mathrm{O}$ flux estimates show that the estuaries are a modest source of $\mathrm{CH}_{4}$ but fluctuate between sources and sinks for $\mathrm{CO}_{2}$ and $\mathrm{N}_{2} \mathrm{O}$ gases.

Keywords: carbon dioxide, distribution of RAGs, Indian sundarban, methane, nitrous oxide, air/water fluxes 


\section{INTRODUCTION}

Rapid changes in the global climate being of primary concern have recently led to investigations regarding the recent developments in the phenomenon of radiative forcing. Currently, the global mole fractions of the gases are at an all-time high (IPCC, 2014). According to IPCC 2014, particularly, the concentrations of the major greenhouse gases like carbon dioxide $\left(\mathrm{CO}_{2}\right)$, methane $\left(\mathrm{CH}_{4}\right)$, and nitrous oxide $\left(\mathrm{N}_{2} \mathrm{O}\right)$ have been major contributors in radiative forcing, more than solar radiation. The radiative equilibrium of the Earth can be influenced by $\mathrm{CO}_{2}, \mathrm{CH}_{4}$, and $\mathrm{N}_{2} \mathrm{O}$, causing a net gain of solar energy by the atmosphere, particularly infrared radiation (IR), which eventually causes warming. These greenhouse gases can, therefore, be termed alternatively as radiatively active gases or RAGs.

Detailed accounts of each of these gases have since been obtained from studies first carried out in the oceans and seas (Bange, 2008; Forster et al., 2009). It is imperative to quantify $\mathrm{CO}_{2}, \mathrm{CH}_{4}$, and $\mathrm{N}_{2} \mathrm{O}$ because the global greenhouse gas flux budget needs accurate information on the contribution of these gases (Khalil et al., 2002; Wuebbles and Hayhoe, 2002).

Natural sources of $\mathrm{N}_{2} \mathrm{O}$ and $\mathrm{CH}_{4}$ account for an estimated $44 \%-54 \%$ of $\mathrm{N}_{2} \mathrm{O}$ emissions (9.6-10.8 $\mathrm{Tg} \mathrm{y}^{-1} \mathrm{~N}_{2} \mathrm{O}$ ) and $30 \%-40 \%$ of $\mathrm{CH}_{4}$ emissions $\left(150-237 \mathrm{Tg} \mathrm{y}^{-1} \mathrm{CH}_{4}\right)$ (IPCC, 2014). In the global list, tropical soils and wetlands make for significant natural sources, contributing approximately $22 \%-27 \%\left(\mathrm{~N}_{2} \mathrm{O}\right)$ and $24 \%$ $\left(\mathrm{CH}_{4}\right)$, respectively, toward this list (Griggs and Noguer, 2002; Whalen, 2005). Spatial emission studies in tropical and subtropical estuarine systems suggest that these areas serve as strong sources of atmospheric $\mathrm{CH}_{4}, \mathrm{~N}_{2} \mathrm{O}$, and $\mathrm{CO}_{2}$ (Guo et al., 2009; Musenze et al., 2014). On the other hand, reports of relatively pristine river-dominated Tay Estuary, United Kingdom (Harley et al., 2015) revealed lower annual emission of RAGs, contradictory to that usually estimated for European estuaries. Again, flux estimation in the Tubul-Raqui estuary, central Chile $\left(36^{\circ} \mathrm{S}\right)$ (Daniel et al., 2013) showed that the estuary acts as a sink for $\mathrm{N}_{2} \mathrm{O}$ but a source for $\mathrm{CH}_{4}$ and $\mathrm{CO}_{2}$. These estimates are teeming with uncertainties when considering distinct environmental features of each estuarine system, such as the extent of stratification, anthropogenic influence, nitrogen budget, and tidal influence (Barnes and Upstill-Goddard, 2011; Alberto V; Borges, 2011; Ivens et al., 2011; Crosswell et al., 2012; Laruelle et al., 2013). Although these areas have notably contributed to the global estimate for RAGs, the values may have been overestimated in most cases, since nutrient-impacted estuaries and macrotidal estuaries have been more in focus for global estimation than their pristine counterparts (Frankignoulle et al., 1998).

In mangrove-dominated estuaries, a significant amount of organic matter, both in dissolved and particulate forms as well as dissolved nutrients, is added to the estuarine water column, resulting in a very complex and dynamic environment for the nutrients. This is because mangroves reportedly store $937 \mathrm{t} \mathrm{C} \mathrm{ha}^{-1}$ organic matter in soil with a mean global burial rate of $174 \mathrm{~g} \mathrm{C} \mathrm{m}^{-1} \mathrm{y}^{-1}$ (Alongi, 2012). These estuaries also have high concentrations of suspended particulate matter (SPM) relative to adjacent coastal waters. The interaction of nutrients and other dissolved species with these particles is an important biogeochemical process in these waters. This SPM is derived from river inputs or resuspension or imported from adjacent coastal waters with a minor contribution from atmospheric inputs.

Microbial processes in the mangrove sediments and water column regenerate organic matter and release dissolved nutrients back to the water column by consuming these suspended particles and organic-rich aggregates. This organic matter regeneration process utilizes dissolved oxygen. This leads to hypoxic, or sometimes anoxic, conditions favoring anaerobic microbial processes like methanogenesis and denitrification. These processes release trace gases like $\mathrm{CH}_{4}$ and $\mathrm{N}_{2} \mathrm{O}$, respectively. The presence of a constant tidal activity helps accumulate large amounts of organic matter in the sediment. This, in turn, prompts redox conditions in the sediment, intensifying the anaerobic processes. Methanogenesis is one of the terminal processes of the anaerobic degradation of carbon. Environments with a high input of organic carbon and less competition from oxidants such as $\mathrm{O}_{2}, \mathrm{NO}_{3}{ }^{-}, \mathrm{Mn}^{4+}, \mathrm{Fe}^{3+}$, and $\mathrm{SO}_{4}{ }^{2-}$ particularly favor methanogenesis. Estuaries are known to be low in $\mathrm{SO}_{4}{ }^{2-}$ concentrations and are hence favorable for methanogenesis (Middelburg et al., 2000). $\mathrm{N}_{2} \mathrm{O}$ production via denitrification may be reduced if $\mathrm{O}_{2}$ and $\mathrm{NO}_{3}{ }^{-}$are absent; $\mathrm{N}_{2} \mathrm{O}$ is consumed by denitrifying bacteria as the terminal electron acceptor. The combined effect causes the sediment porewater to be enriched with $\mathrm{CH}_{4}$ and $\mathrm{N}_{2} \mathrm{O}$, which, finally through advective transport, enriches the level of those gases in the estuarine water column. Denitrification can also occur in the water column alongside nitrification, where $\mathrm{NH}_{4}{ }^{+}$is oxidized to $\mathrm{NO}_{2}{ }^{-}$, releasing $\mathrm{N}_{2} \mathrm{O}$ as a byproduct (Bange, 2008). Both the processes rely heavily on the available dissolved oxygen content (Brase et al., 2017). $\mathrm{CH}_{4}$ and $\mathrm{N}_{2} \mathrm{O}$ are important biogenic trace gases and together account for $\sim 20 \%$ enhanced greenhouse forcing (Forster et al., 2009). Current best estimates are that marine waters provide $<5 \%$ of tropospheric $\mathrm{CH}_{4}$ and $29 \%-55 \%$ of tropospheric $\mathrm{N}_{2} \mathrm{O}$; the highest contributions are from estuaries and shallow coastal shelves (Seitzinger and Kroeze, 1998).

For our study, we have stressed 1) the distribution of $\mathrm{CO}_{2}$, $\mathrm{CH}_{4}$, and $\mathrm{N}_{2} \mathrm{O}$, the three major radiatively active gases (also called greenhouse gases) in water, and 2) their flux dynamics in the Indian Sundarban, comprising the Saptamukhi-Thakuran-Matla estuarine region concerning spatial, diel, and seasonal variability. The chosen area is a comparatively pristine buffer zone with no previous reports based on wide spatial coverage of the three RAGs together. Hypothesizing the fact that these estuaries are a source of $\mathrm{CO}_{2}, \mathrm{CH}_{4}$, and $\mathrm{N}_{2} \mathrm{O}$, the dissolved concentrations were used to calculate the air/water fluxes for each station. The findings from our study can be contributory to further research on the biogeochemical processes related to the production of $\mathrm{CO}_{2}$, $\mathrm{CH}_{4}$, and $\mathrm{N}_{2} \mathrm{O}$ in the Indian part of Sundarban.

\section{MATERIAL AND METHODS}

\section{Study Site}

The Indian Sundarban estuaries, about $40 \%$ of the total Sundarban shared between India and Bangladesh, are situated 


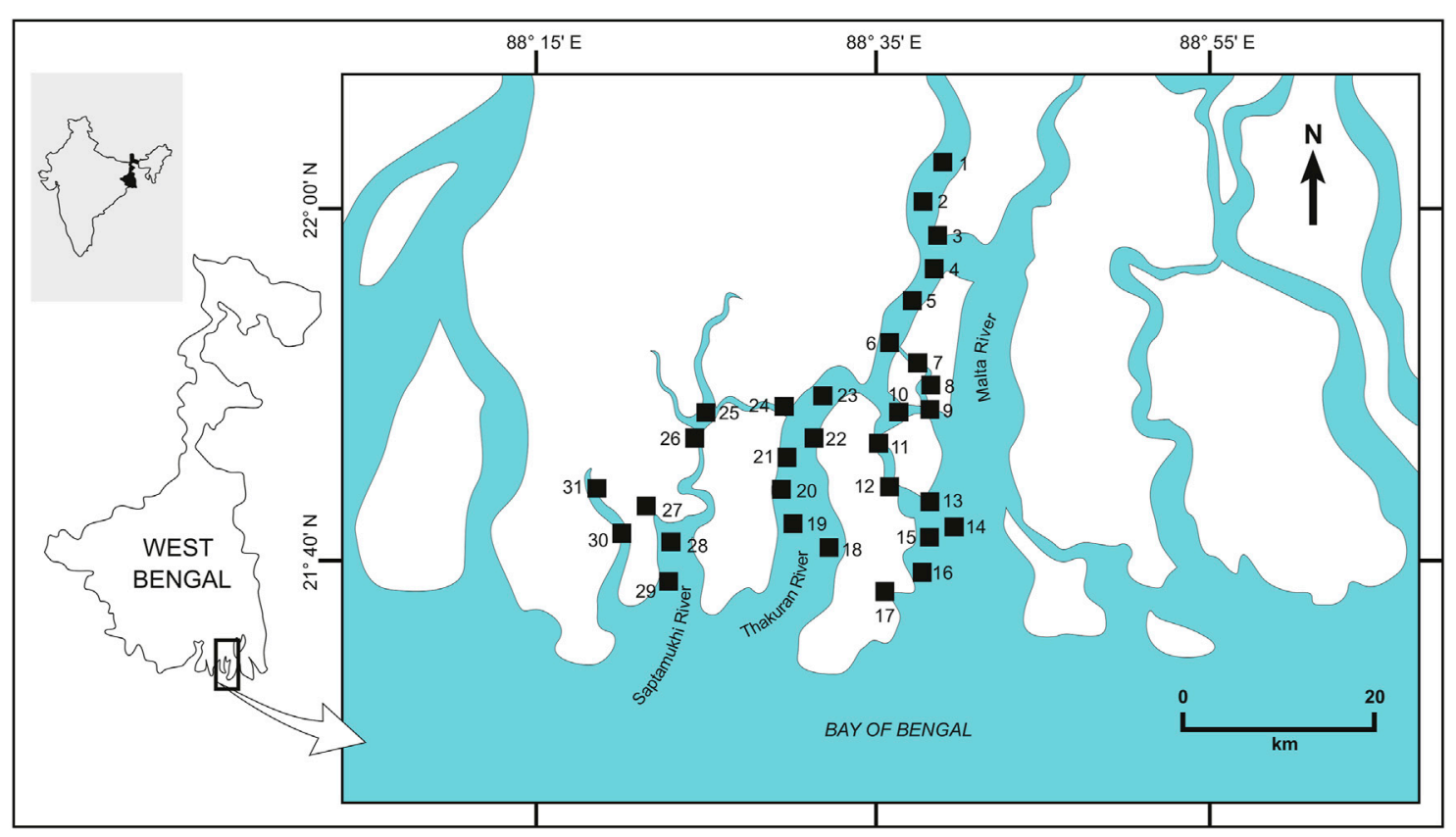

FIGURE 1 | Map of the study area showing points off observation in the Indian Sundarban region.

on the northeast coast of India and drain into the Bay of Bengal. The estuary has an area of $1,800 \mathrm{~km}^{2}$ (Dutta et al., 2019) with a tidal range of 4.32 and $5.58 \mathrm{~m}$ (Chatterjee et al., 2013). The intertidal area is $45 \%$ of $4,260 \mathrm{~km}^{2}$ (Dutta et al., 2017). Overall, the estuaries have a mean depth of $\sim 6 \mathrm{~m}$ (Dutta et al., 2019) with a semidiurnal tide pattern and limited freshwater supply, making the estuaries marine dominated (Dutta et al., 2015). The estuaries receive partial anthropogenic inputs in the monsoon. The mean annual rainfall is $1,973 \mathrm{~mm}$, most of which is received by the area between the months of June and September (Ray et al., 2013).

The Indian part of Sundarban stretches for approximately $50-70 \mathrm{~km}$ from the north to the southern margin of the Bay of Bengal and $140 \mathrm{~km}$ from east to west. For the study, the estuaries Saptamukhi, Thakuran, and Matla were chosen as they have several interconnected channels exhibiting the semi-diurnal tidal nature and forming a major part of the Indian Sundarban estuaries (Sanyal et al., 2020).

The Saptamukhi estuary, located at $21.604^{\circ} \mathrm{N}$ and $88.352^{\circ} \mathrm{E}$, shows a tidal range of $1.8-5.2 \mathrm{~m}$ (Mukhopadhyay et al., 2006). It is about $41 \mathrm{~km}$ long and $10 \mathrm{~km}$ wide. It receives a considerable amount of inputs from agricultural lands and other anthropogenic sources via run-off but has no perennial source of freshwater. Several mangrove-dominated islands, some of which also have human settlements, flank the waters. Its eastern part is stronger and widens in its last $10 \mathrm{~km}$ to the Bay of Bengal.

With similar tide conditions and mangrove-dominated islands, the Thakuran estuary is located at $21.658{ }^{\circ} \mathrm{N}$ and $88.492^{\circ} \mathrm{E}$. About $62 \mathrm{~km}$ long and $10 \mathrm{~km}$ wide, this estuary is situated close to the Bay of Bengal. The mouth of the Thakuran estuary is vulnerable to bank erosion. The mid- channel bars show varying sediment compositions ranging from mud to sand (Das, 2016).

Of the two estuaries, the Matla estuary $\left(21.603^{\circ} \mathrm{N}, 88.655^{\circ} \mathrm{E}\right)$, runs the longest distance from Canning to the Bay of Bengal. At its head, human settlement and agriculture are now common activity. Currently subject to heavy sedimentation, its depth has shortened considerably to about 2-6 m (Akhand et al., 2021). The mouth of the estuary is about $26 \mathrm{~km}$ wide, which allows substantial amounts of marine waters of the Bay of Bengal to flow in at high tide. The present conditions of the Matla suggest that both human intervention and forces have led to a considerable reduction in its freshwater supply.

\section{Water Sampling and Analysis}

Water samples from the estuaries were collected for the measurement of physicochemical parameters and RAG concentrations from a hired mechanized boat from 31 stations from April 2016 to August 2019 (Figure 1). On sampling occasions of July 2017, June 2019, and August 2019, the sampling was conducted over a $24 \mathrm{~h}$ period, with samples collected every $2 \mathrm{~h}$, at one site (site 27), Lothian island, located at the confluence of the Saptamukhi estuary and the Bay of Bengal (Biswas et al., 2007), to assess the temporal variation over three full tidal cycles and compare them. Water samples were collected using 5 L Niskin bottles (OceanTest Equipment, Fort Lauderdale, FL, USA). Subsamples for dissolved oxygen (DO), nutrients (nitrate and ammonium), chlorophyll- $a$, and total alkalinity were collected in triplicate Niskin sampling at all stations.

Water temperature and salinity were recorded using a conductivity-temperature-depth profiler (SBE 19 plus; Sea- 
Bird Electronics, Bellevue, WA, USA $)( \pm 0.005$ standard deviation) and deployed bi-hourly for diurnal observations. DO was sampled in $125 \mathrm{ml}$ glass DO bottles and estimated by Winkler's titrimetric method with $\pm 3.6 \mu \mathrm{M}$ standard deviation between duplicates. Nutrients were filtered in GF/F $0.45 \mu \mathrm{m}$ filter papers and filtrates analyzed as per standard protocols (Wangersky, 1978) at $\pm 0.02 \mu \mathrm{M}$ standard deviation. Chlorophyll-a (chl-a) subsamples were collected in $500 \mathrm{ml}$ HDPE dark bottles and filtered using $47 \mathrm{~mm}$ GF/F filter papers (pre-combusted at $350^{\circ} \mathrm{C}$ for $4 \mathrm{~h}$ ), which were later stored in Cryochill $^{\mathrm{TM}}$ vials and transported back to the laboratory in a liquid nitrogen can. Subsequently, chl- $a$ was measured using the spectrophotometric method (Parsons et al., 1984) with an analytical precision of $\pm 2.5 \%$. $\mathrm{pH}$ (NBS scale) and water temperature were measured onboard immediately after sampling using Ross combination electrode $\mathrm{pH}$ meter (Orion Star A211) fitted with an additional water temperature sensor. Total alkalinity (TA) was measured after bringing the samples back to the laboratory preserved in $60 \mathrm{ml}$ polypropylene bottles with $30 \mu \mathrm{l}$ saturated mercuric chloride $\left(\mathrm{HgCl}_{2}\right)$, using the potentiometric titration method in an open cell at $25^{\circ} \mathrm{C}$ at 0.78\% uncertainty (Steven Bouillon et al., 2003; Chou et al., 2013) when tested against Dickson Standard (CRM131-0,215). Unfiltered DIC samples were determined using a coulometer (Model Coulometer CM5017; UIC Inc., Joliet, IL, USA). The mean relative uncertainty of DIC was found to be $4.6 \%$ when tested against the same Dickson Standard. Wind speed was logged continuously using Weather Station (Davis Vantage Pro2, USA) fitted on the roof of the boat at $10 \mathrm{~m}$ above.

\section{Measurement of Dissolved $\mathrm{CO}_{2}, \mathrm{CH}_{4}$, and $\mathrm{N}_{2} \mathrm{O}$}

Gas concentrations were determined using the headspace method in surface water sampled in triplicate at $\sim 0.5 \mathrm{~cm}$ from the surface waters from each study point. The water samples were collected in $60 \mathrm{ml}$ borosilicate vials right after the collection of DO samples. Samples were preserved immediately from microbial activity using $30 \mu \mathrm{l}$ saturated mercuric chloride $\left(\mathrm{HgCl}_{2}\right)$ and sealed using a rubber septum and aluminum cap. $\mathrm{CH}_{4}$ and $\mathrm{N}_{2} \mathrm{O}$ were analyzed on a Trace 1,110 gas chromatograph (M/s. Thermo) with a built-in flame ionization detector and an electron capture detector for $\left[\mathrm{N}_{2} \mathrm{O}\right]$ was used for the determination of dissolved gas concentrations. Concentrations were determined from the peak areas of a set of two standard gas mixtures $\left(\mathrm{CH}_{4} / \mathrm{N}_{2} \mathrm{O}: 183 /\right.$ $0.517 ; 414 / 1.0 \mathrm{ppm})$ with an accuracy of $\pm 5 \%$. The dissolved concentrations were expressed as $\mathrm{nmol} \mathrm{L}^{-1}$ for $\mathrm{CH}_{4}$ and $\mathrm{N}_{2} \mathrm{O}$ (Bange et al., 2019). The standard runs were included before and after the analysis. The concentrations of dissolved (and expected saturation percent concerning atmospheric concentration) $\mathrm{CH}_{4}$ and $\mathrm{N}_{2} \mathrm{O}$ were calculated from the concentrations measured from the headspace using solubility coefficients as a function of temperature and salinity given by (Wiesenburg and Guinasso Jr, 1979; Weiss and Price, 1980). Saturation percents for the gases were determined as the ratio of the concentration of the dissolved gas and the expected atmospheric equilibrium water concentrations.
The partial pressure of dissolved $\mathrm{CO}_{2}$ was expressed as $\mu$ atm and obtained from CO2SYS software (Excel version 2.3) using the TA-DIC couple, dissociation constants of salinity range 0-40 (Cai and Wang, 1998), and $\mathrm{KHSO}_{4}$ constant (Dickson, 1990). The propagated uncertainty of the calculated $\mathrm{pCO}_{2}$ was found to be 2.1\% (Hoppe et al., 2010; Orr et al., 2018).

\section{Calculating $\mathrm{CO}_{2}, \mathrm{CH}_{4}$, and $\mathrm{N}_{2} \mathrm{O}$ Air/Water Fluxes From the Estuaries}

The air/water gas fluxes $\left(\mathrm{WA}-\mathrm{F}_{\mathrm{Gas}}\right.$ ) were calculated using

$$
W A-F_{G a s}=k_{i}\left([G a s]_{w}-[G a s]_{e q}\right)
$$

where $k_{i}\left(\mathrm{~cm} \mathrm{~h}^{-1}\right)$ is the gas transfer velocity, $[\mathrm{Gas}]_{w}(\mathrm{nmol} \mathrm{L}-1)$ is the dissolved gas concentration, and $[\mathrm{Gas}]_{e q}\left(\mathrm{nmol} \mathrm{L}{ }^{-1}\right)$ is the dissolved concentration at equilibrium with the appropriate atmospheric concentration. As $k$ was not measured in our study, gas fluxes were estimated, applying four parameterizations of $k$ based on their widespread use in the literature (Clark et al., 1995; Raymond and Cole, 2001; Ho et al., 2011; Wanninkhof, 2014).

C95: Clark et al. (1995):

$$
k_{600}=2.0+0.24\left(u_{10}\right)
$$

RC01: Raymond and Cole (2001):

$$
k_{600}=1.91 \times e^{0.35 u} 10
$$

H11: Ho et al. (2011):

$$
k_{600}=a+0.266\left(u_{10}\right)^{2}
$$

W14: Wanninkhof (2014):

$$
k_{600}=0.25 \times u 10^{2}
$$

where $k_{600}$ is the gas transfer velocity of $\mathrm{CO}_{2}$ normalized to $20^{\circ} \mathrm{C}$ $\left(\mathrm{cm} \mathrm{h}^{-1}\right)$ and $u_{10}$ is the mean wind speed $\left(\mathrm{m} \mathrm{s}^{-1}\right)$ of each month of the sampling campaign, calculated from the continuous wind speed measured daily using a Davis Vantage Pro2 portable weather station (United States). The "a" in H11 equation was considered 0 based on the depth and the dimension of the estuary studied (Akhand et al., 2021). The water temperature and salinity influence the gas transfer velocity, which again differs among gases. From the obtained values of $k_{600}, k_{i}$ was calculated at the observed temperature and salinity in the field measurements following the method of Ferrón et al. (2007a):

$$
k_{i}=k_{600}\left(S c_{i} / S c_{600}\right)^{-0.5}
$$

$S c_{i}$ is the Schmidt number, the ratio of the kinematic viscosity of water to the diffusivity of the gas, and is calculated using the method of Wanninkhof (2014), assuming that $S c_{i}$ varies linearly with salinity and $k_{i}$ is directly proportional to $S c^{-0.5}$ (Ferrón et al., 2007b; Harley et al., 2015). The fluxes were expressed in $\mathrm{mmol} \mathrm{m} \mathrm{m}^{-2} \mathrm{~h}^{-1}$ for $\mathrm{CO}_{2}$ and in $\mu \mathrm{mol} \mathrm{m} \mathrm{h}^{-2}$ for $\mathrm{CH}_{4}$ and $\mathrm{N}_{2} \mathrm{O}$.

The calculated $k$ values were then used to obtain the gas flux density using Eq. 1 and extrapolated to the total estuarine area of $1,800 \mathrm{~km}^{2}$ (Dutta et al., 2019) by multiplying the total estuary area 
to the mean flux density $(\mathrm{n}=244)$ and expressed as yearly emission. The fluxes were also expressed as $\mathrm{CO}_{2}$ equivalents by multiplying emissions by their global warming potentials (GWPs); 1 for $\mathrm{CO}_{2}, 28$ for $\mathrm{CH}_{4}$, and 265 for $\mathrm{N}_{2} \mathrm{O}$.

\section{Analysis of Sediment/Air and Sediment/ Water RAG Fluxes From Intertidal Sediments}

The fluxes $\left(\mathrm{CO}_{2}, \mathrm{CH}_{4}\right.$, and $\left.\mathrm{N}_{2} \mathrm{O}\right)$ from the intertidal sediments of the mangrove systems were done by collecting the gas samples by using the 'manual closed chamber method' (Bhattacharyya et al., 2013a, 2016) at site 27 close to the Saptamukhi estuary. Chamber deployment was not allowed in other sites due to government restrictions. In this method, the gas samples for RAG fluxes $\left(\mathrm{CO}_{2}\right.$, $\mathrm{CH}_{4}$, and $\left.\mathrm{N}_{2} \mathrm{O}\right)$ were collected from the Perspex chamber $(53 \times$ $37 \times 51 \mathrm{~cm}^{3}$ ) set at the lower, middle, and upper littoral zones respectively at each study site. A battery-operated air circulation pump with an air displacement of $1.5 \mathrm{~L} \mathrm{~min}^{-1}$ was connected to a polyethylene tubing to mix the air inside the chamber and draw the air samples into a plastic syringe (Bhattacharyya et al., 2013b) at 0,15 , and 30 -min intervals. For this system, gas samples were collected in presence of the pneumatophores in sediments. The gas samples were collected at 20 locations within the site with three replicates. The RAG concentrations were then analyzed by using gas chromatography (Model no: Trace 1,110 Gas Chromatograph; M/s Thermo).

The sediment/air RAG flux was calculated following the method of (Collier et al., 2014; Kahmark and Millar, 2020). The slope of $\mathrm{T}_{0}, \mathrm{~T}_{15}$, and $\mathrm{T}_{30}$ concentrations over time was determined, in ppmv $\mathrm{min}^{-1}$, equivalent to $\mu \mathrm{l}^{-1} \mathrm{~min}^{-1}$. The slope was designated as $\alpha_{v}$. This slope was converted to the unit of mass designated as $\alpha_{\mathrm{m}}$, in $\mu \mathrm{g} \mathrm{l}^{-1} \mathrm{~min}^{-1}$ and corrected for field temperature applying the ideal gas law:

$$
\alpha_{m}=\left(\alpha_{v} \times M \times P\right) /(R \times T)
$$

where: $\alpha_{\mathrm{m}}$ is $\mu \mathrm{g}$ RAG $\mathrm{l}^{-1} \mathrm{~min}^{-1} ; \mathrm{M}=$ molar weight of RAG $\left(44 \mu \mathrm{g} \mu \mathrm{mol}^{-1} \mathrm{CO}_{2}\right.$ or $\mathrm{N}_{2} \mathrm{O}$ or $\left.16 \mu \mathrm{g} \mu \mathrm{mol}^{-1} \mathrm{CH}_{4}\right) ; p=1 \mathrm{~atm}$ (standard atmospheric pressure); $\mathrm{R}=$ universal gas constant = $0.0821 \mu \mathrm{latm} \mu \mathrm{mol}^{-1} \mathrm{~K}^{-1}$; $\mathrm{T}=$ field temperature, in $\mathrm{K}={ }^{\circ} \mathrm{C}+273$.

The flux $\left(S A-F_{G a s}\right)$ of RAG was then calculated as $\mu \mathrm{g}$ RAG $\mathrm{m}^{-2} \mathrm{~h}^{-1}$ using the following equation:

$$
S A-F_{\text {Gas }}=\left(\alpha_{m} \times V \times 60\right) / A
$$

where: $\alpha_{\mathrm{m}}$ is $\mu \mathrm{g} \mathrm{RAG}^{-1} \mathrm{~min}^{-1}$; $\mathrm{V}$ is the volume of the gas in the chamber in $\mathrm{l}$; and $\mathrm{A}=$ sediment surface areas covered by the chamber in $\mathrm{m}^{2}$. The fluxes were finally expressed in terms of moles to ease the comparison with the air/water RAG fluxes.

To verify the influence of intertidal areas on the RAG fluxes in the estuary, porewater samples were collected from $1 \mathrm{~m}$ deep pit holes made into 14 locations using a steel corer in the intertidal zones around sites 17, 19, and 27 on the sampling occasions of April 2019, June 2019, and August 2019. The porewater samples were collected into $500 \mathrm{ml}$ PVC bottles using a manually operated suction pump. Porewater salinity was also measured using the Mohr-Knudsen method. RAG concentrations were measured using the same gas chromatograph from the porewater samples to calculate the advective transport of the gases from sediment porewater to adjacent estuarine water on sampling occasions. The advective transport was then calculated using the formula:

$$
F_{I S W}=d \times[\text { Gas }]_{I S W}
$$

where $\mathrm{d}=$ specific discharge and $[\mathrm{Gas}]_{\mathrm{ISw}}=$ porewater $\mathrm{RAG}$ concentration in the sediment (interstitial water). The mean specific discharge of $0.006 \mathrm{~cm} \mathrm{~min}^{-1}$ (Dutta et al., 2015) was used to calculate the $F_{I S W}$. The fluxes were expressed in terms of moles.

\section{Statistical Analyses}

Statistical analysis was performed using Minitab version 18. A seasonality index was produced by splitting the data into two groups: late monsoon/post-monsoon (December 2018, November 2016, December 2018, January 2019, and January 2020) and premonsoon/early monsoon (April 2016, May 2017, June 2017, July 2017, October 2017, March 2018, September 2018, April 2019, June 2019, and August 2019). Given its six-month-long duration, the monsoon period was subcategorized into early and late monsoon to address differences in gas saturations within the period. The premonsoon/early monsoon means were divided by the late-monsoon/ post-monsoon means to derive the seasonality index for the estuary and each sampling site. Index values close to 1 would indicate little seasonal difference, while values above 1 would mean higher gas saturations in pre-monsoon/early monsoon than late monsoon/ post-monsoon (Harley et al., 2015). Significant differences between the two pairs of saturation were tested with two-sample t-tests. A two-way analysis of variance was also applied on the gas saturations, air/water, and sediment/water fluxes based on estuary and season as factors to assess the spatial and seasonal variability, while light and tide were factors (high tide or low tide) chosen to assess the tidal variability. Spearman rho correlation coefficients were then calculated to examine relationships between the measured gas saturations and other physicochemical parameters. In addition, the stepwise regression of gas saturation with other physicochemical parameters was performed to discern the key factors controlling the variability of the gas saturation.

\section{RESULTS AND DISCUSSION}

\section{Spatial Pattern}

All the gases and the associated physicochemical parameters of the estuaries showed random distributions against distance from the mouth of the estuary (Figure 2). This meant that no distinct increasing or decreasing pattern was found in the gases and the parameters that suggest little hydrological differences between the three estuaries, owing to their well-mixed nature (Dutta et al., 2015).

$\mathrm{N}_{2} \mathrm{O}$ saturations ranged from 8 to $1,286 \%$ (Figure 2). However, the majority of the saturation values lay within $400 \%$. The distribution was random throughout the extent of the study area, corroborating the studies on $\mathrm{N}_{2} \mathrm{O}$ that identify the 


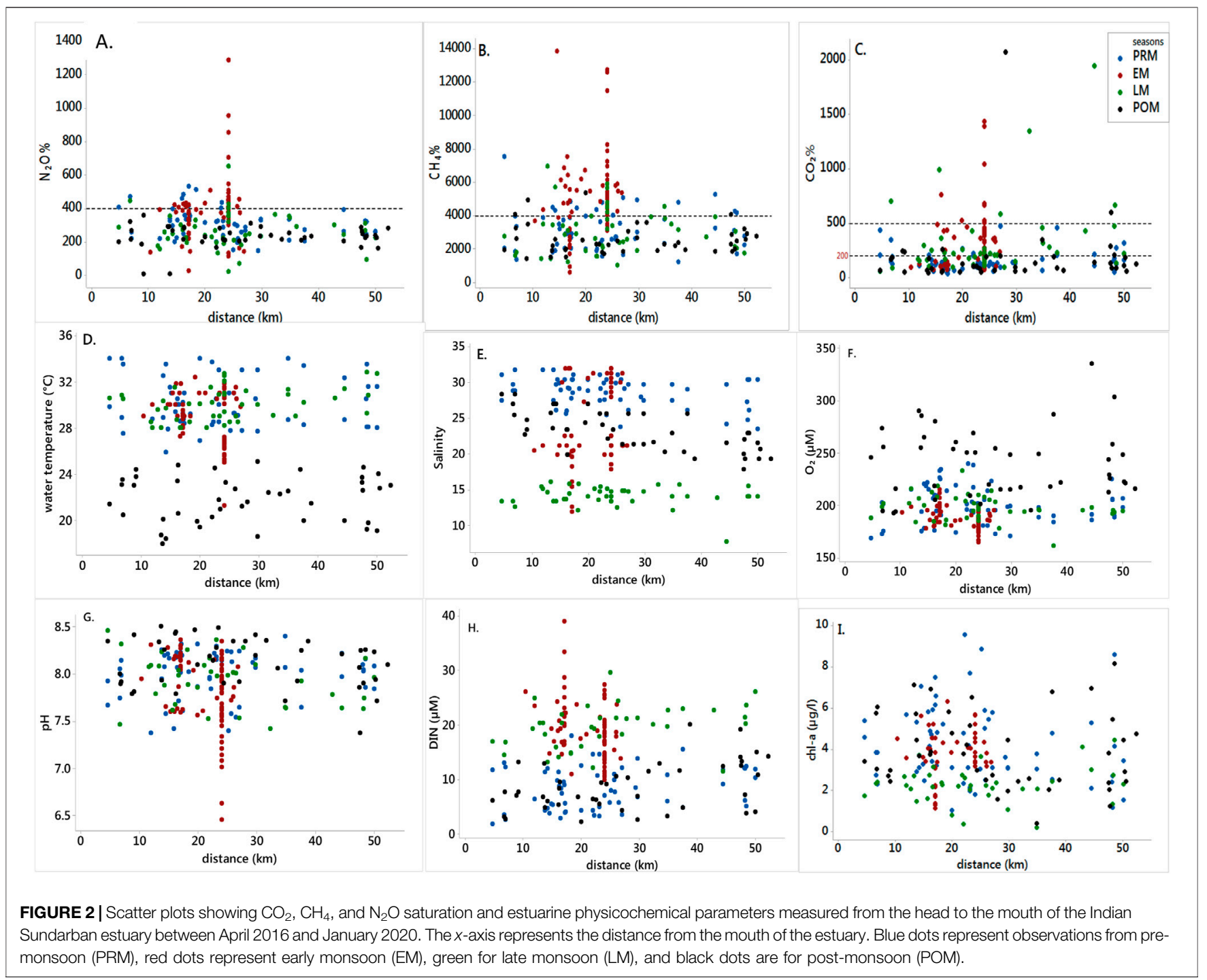

gas as spatially heterogeneous (Murray et al., 2015). According to sampling campaigns, maximum saturation could be observed in June 2019 (mean of $473 \%$ ), while the minimum mean saturation of $180 \%$ was recorded in November 2016. Being an organic material-rich system, which receives a huge mangrove litterfall and marine algae as significant ways of nutrient input via tidal pumping (Sanyal et al., 2020), the overall mean $\mathrm{N}_{2} \mathrm{O}$ saturation percent of $317 \pm 134 \%$ in the Indian Sundarban was higher than those of the Arabian Sea (mean of $186 \pm 37 \%$ ) (Naqvi and Noronha, 1991) and the Bay of Bengal $(81 \pm 6 \%)$ (Rao et al., 2013a). The means of $\mathrm{N}_{2} \mathrm{O} \%$ saturation of the three estuaries showed significant differences $(\mathrm{F}=4.25 ; p=0.015)$. The saturation was higher in the Saptamukhi (mean of $352 \pm$ $176 \%$ ) than in the other two (Thakuran: $284 \pm 119 \%$ and Matla: $302 \pm 112 \%$ ) estuaries. This could be due to the anthropogenic input in the form of run-off from the agricultural lands close to the Saptamukhi estuary (Dutta et al., 2015), which brings in nitrogenous fertilizer waste, adding to the inorganic nitrogen substrate in the estuary (Ray et al., 2014). Furthermore, a portion of the anthropogenicinfluenced Hooghly estuary flows into the Saptamukhi estuary (Sanyal et al., 2020) bringing in more inorganic nitrogen material. Coupled together, these two inputs may have enhanced $\mathrm{N}_{2} \mathrm{O}$ production in the Saptamukhi estuary, thereby increasing its $\mathrm{N}_{2} \mathrm{O}$ $\%$ compared to the other two estuaries.

Indian Sundarban estuaries showed higher average $\mathrm{N}_{2} \mathrm{O} \%$ than other Indian estuaries, which showed an average $\mathrm{N}_{2} \mathrm{O} \%$ ranging between $108 \pm 53 \%$ and $292 \pm 150 \%$ (Rao and Sarma, 2013b). Unlike other Indian estuaries that experience high flushing time during discharge along with adequate freshwater supply to wash away most of the fertilizer waste accumulated in the waters, the Sundarban estuaries receive a limited freshwater discharge that causes the materials to linger in the system, thus facilitating $\mathrm{N}_{2} \mathrm{O}$ production. Similar to the pattern of $\mathrm{N}_{2} \mathrm{O}$ in other Indian estuaries (Rao and Sarma, 2013b), the overall significant positive correlation between $\mathrm{N}_{2} \mathrm{O} \%$ and $\mathrm{NH}_{4}{ }^{+}$along with water temperature, salinity, and chl- $a$ concentrations and negative correlation with $\mathrm{O}_{2}$ concentration in the Indian 
TABLE 1 | Spearman's correlation coefficient for pooled data $(n=225)$ and by seasons $(n=57)$ (values marked in bold are significant $(p<0.05)$.

\begin{tabular}{|c|c|c|c|c|c|}
\hline & All data & PRM & EM & LM & POM \\
\hline & $\mathrm{CO}_{2} \%$ & $\mathrm{CO}_{2} \%$ & $\mathrm{CO}_{2} \%$ & $\mathrm{CO}_{2} \%$ & $\mathrm{CO}_{2} \%$ \\
\hline $\mathrm{CH}_{4} \%$ & 0.34 & 0.34 & 0.32 & 0.08 & 0.16 \\
\hline $\mathrm{N}_{2} \mathrm{O} \%$ & 0.20 & -0.07 & 0.29 & 0.18 & 0.02 \\
\hline Water temp. ( $\left.{ }^{\circ} \mathbf{C}\right)$ & 0.35 & 0.56 & 0.38 & -0.02 & 0.25 \\
\hline Salinity & 0.03 & 0.16 & 0.46 & 0.12 & -0.06 \\
\hline$\left[\mathrm{O}_{2}\right]$ & -0.41 & -0.54 & -0.33 & 0.10 & -0.28 \\
\hline $\mathrm{pH}$ & -0.76 & -0.40 & -0.86 & -0.97 & -0.8 \\
\hline$\left[\mathrm{NO}_{3}{ }^{-}\right]$ & 0.31 & 0.53 & -0.22 & -0.13 & -0.05 \\
\hline$\left[\mathrm{NH}_{4}^{+}\right]$ & -0.02 & -0.12 & -0.34 & 0.10 & 0.06 \\
\hline CHL-a & -0.17 & -0.30 & 0.19 & 0.05 & -0.25 \\
\hline \multirow[t]{2}{*}{ [DIN] } & 0.25 & 0.48 & -0.43 & -0.09 & 0.06 \\
\hline & $\begin{array}{l}\text { All data } \\
\mathbf{C H}_{4} \%\end{array}$ & $\begin{array}{l}\mathrm{PRM} \\
\mathbf{C H}_{4} \%\end{array}$ & $\begin{array}{c}\mathrm{EM} \\
\mathbf{C H}_{4} \%\end{array}$ & $\begin{array}{c}\mathrm{LM} \\
\mathbf{C H}_{4} \%\end{array}$ & $\begin{array}{l}\mathrm{PON} \\
\mathbf{C H}_{4}\end{array}$ \\
\hline \multicolumn{6}{|l|}{$\mathrm{CH}_{4} \%$} \\
\hline $\mathbf{N}_{2} \mathrm{O} \%$ & 0.54 & 0.26 & 0.24 & 0.56 & 0.25 \\
\hline WT ( $\left.{ }^{\circ} \mathrm{C}\right)$ & 0.32 & 0.65 & 0.02 & 0.17 & 0.13 \\
\hline Salinity & 0.17 & 0.55 & 0.14 & -0.28 & 0.08 \\
\hline$\left[\mathrm{O}_{2}\right]$ & -0.48 & -0.30 & -0.17 & -0.21 & -0.2 \\
\hline pH & -0.37 & -0.36 & -0.27 & -0.26 & -0.1 \\
\hline$\left[\mathrm{NO}_{3}{ }^{-}\right]$ & 0.19 & 0.67 & -0.34 & -0.12 & -0. \\
\hline$\left[\mathrm{NH}_{4}^{+}\right]$ & 0.31 & 0.46 & -0.33 & 0.32 & -0.1 \\
\hline CHL-a & 0.16 & -0.18 & 0.48 & 0.02 & -0.1 \\
\hline \multirow[t]{2}{*}{ [DIN] } & 0.26 & 0.76 & -0.45 & -0.01 & -0.1 \\
\hline & $\begin{array}{l}\text { All data } \\
\mathbf{N}_{2} \mathbf{O} \%\end{array}$ & $\begin{array}{c}\text { PRM } \\
\mathbf{N}_{2} \mathbf{O} \%\end{array}$ & $\begin{array}{c}E M \\
\mathbf{N}_{2} \mathbf{O} \%\end{array}$ & $\begin{array}{c}\mathrm{LM} \\
\mathbf{N}_{2} \mathbf{O} \%\end{array}$ & $\begin{array}{l}\text { POM } \\
\mathbf{N}_{2} \mathbf{O} \%\end{array}$ \\
\hline \multicolumn{6}{|l|}{$\mathrm{CH}_{4} \%$} \\
\hline \multicolumn{6}{|l|}{$\mathrm{N}_{2} \mathrm{O} \%$} \\
\hline WT ( $\left.{ }^{\circ} \mathrm{C}\right)$ & 0.35 & 0.05 & 0.44 & 0.35 & -0.0 \\
\hline Salinity & 0.29 & 0.08 & 0.53 & -0.29 & 0.01 \\
\hline$\left[\mathrm{O}_{2}\right]$ & -0.43 & 0.04 & -0.56 & -0.44 & 0.03 \\
\hline pH & -0.24 & 0.09 & -0.35 & -0.44 & 0.16 \\
\hline$\left[\mathrm{NO}_{3}{ }^{-}\right]$ & 0.09 & 0.10 & -0.19 & -0.49 & 0.04 \\
\hline$\left[\mathrm{NH}_{4}^{+}\right]$ & 0.23 & 0.09 & -0.17 & 0.22 & -0.24 \\
\hline CHL-a & 0.23 & 0.11 & 0.35 & -0.18 & 0.11 \\
\hline [DIN] & 0.09 & 0.09 & -0.31 & -0.41 & -0.0 \\
\hline
\end{tabular}

Sundarban estuaries suggest that estuarine nitrification is a possible pathway for $\mathrm{N}_{2} \mathrm{O}$ production. A stepwise regression between $\mathrm{N}_{2} \mathrm{O} \%$ and the key physicochemical parameters as independent variables resulted in salinity, $\mathrm{O}_{2}$ concentration, and $\mathrm{pH}$ being significant factors $(p<0.05)$ on $\mathrm{N}_{2} \mathrm{O} \%\left(\mathrm{~N}_{2} \mathrm{O} \%\right.$ $\left.=1,310+5.77 \mathrm{~S}-0.886\left[\mathrm{O}_{2}\right]-120.8 \mathrm{pH} ; R^{2}=29.9 \%\right)$. However, these parameters could explain only about $30 \%$ of the variability in $\mathrm{N}_{2} \mathrm{O} \%$, implying the contribution of other external factors that influence $\mathrm{N}_{2} \mathrm{O}$ in the Sundarban estuaries.

$\mathrm{CH}_{4}$ dynamics have been studied in great detail in previous studies on the Indian Sundarban estuaries (Biswas et al., 2007; Dutta et al., 2013, 2015; Dutta and Mukhopadhyay, 2016). $\mathrm{CH}_{4}$ concentration in the Indian Sundarbans has been suggested to be exogenous (Biswas et al., 2007; Dutta et al., 2015); in other words, advective and diffusive transport of $\mathrm{CH}_{4}$ from the sediment to the estuary dominates the $\mathrm{CH}_{4}$ concentration in the estuary waters. The mean $(3,280 \%)$ measured in our study is within the range of mean values reported from another study in the Saptamukhi $(2,483.02 \pm 50.18$ to $3,525.45 \pm 1,053.72)$ (Dutta et al., 2015). The range $(1,020 \%-13,844 \%)$ is narrower than the values reported for other Indian estuaries (180\%-22,340\% (Rao and Sarma, 2016)). Similar to $\mathrm{N}_{2} \mathrm{O}$, there was no spatial pattern in $\mathrm{CH}_{4}$ saturation as well (Figure 2). The saturation values were highly random throughout the study area. The saturation range was dispersed over the entire study area, with no specific increasing or decreasing pattern from the head to the mouth of the estuary. The lack of a steady pattern in the distribution of $\mathrm{CH}_{4}$ saturation indicated that the degradation of organic matter loads varied among study points along with varying advective transport rates from the adjacent intertidal sediments. The advective signal coupled with well-mixed nature finally rendered the $\mathrm{CH}_{4}$ distribution as random.

$\mathrm{CH}_{4}$ saturation, in general, was significantly correlated with all physicochemical parameters for our study period (Table 1) suggesting that estuarine physicochemical water parameters played a significant role in controlling $\mathrm{CH}_{4}$ dynamics in addition to the advective transport of $\mathrm{CH}_{4}$ from the intertidal sediments. Contrary to previous studies, $\mathrm{CH}_{4}$ saturation and salinity, in general, were found to be positively correlated in our study for a salinity range from 11.9 to 31.9 . This could be due to highly saline porewater from the intertidal areas entering the estuary waters (range: 19.8-54.2 for our study period). This positive correlation between $\mathrm{CH}_{4}$ saturation and salinity for our system is in contrast to other Indian estuaries where freshwater acts as a significant source for $\mathrm{CH}_{4}$ (Rao and Sarma, 2016). A further stepwise regression on $\mathrm{CH}_{4} \%$ pinpointed water temperature, salinity, $\mathrm{pH}, \mathrm{NO}_{3}{ }^{-}$, and DIC to be significant factors $(p<0.05)$ in controlling its dynamics $\left(\mathrm{CH}_{4} \%\right.$ $=6,911+79.2 \mathrm{WT}\left({ }^{\circ} \mathrm{C}\right)+101.3$ salinity $-848 \mathrm{pH}+71.4 \mathrm{NO}_{3}+$ $55.9 \mathrm{NH}_{4}-1.417$ DIC; $R^{2}=30.7 \%$ ) although only about $30 \%$ of the variability could be attributed to these parameters.

$\mathrm{CO}_{2}$ dynamics have also been studied exhaustively in the Indian Sundarbans in recent years. Throughout the study period, $\mathrm{CO}_{2}$ saturation ranged from 30 to $2,075 \%(\mathrm{n}=229)$. A few of the measurements indicated undersaturation ranging from 30 to $98 \%(n=54)$, while the majority of the estuary waters was predominantly supersaturated with $\mathrm{CO}_{2}$, with supersaturation ranging from 101 to $2,075 \%(\mathrm{n}=175)$. The highest $\mathrm{CO}_{2}$ saturations were in June 2019 (mean of 471\%) and the lowest in January 2020 (mean of 48\%). Our range of $\mathrm{CO}_{2}$ saturation is much larger than those reported in the earlier studies [76\%-156\%, Thakuran estuary, and 81\%-289\% Matla estuary (Akhand et al., 2021; Akhand et al., 2021b)]. The difference could be due to larger spatial coverage than the previous studies. The distribution of $\mathrm{CO}_{2}$ saturation per cent in the Indian Sundarban estuary did not vary among the estuaries (Figure 2). The $\mathrm{CO}_{2}$ saturation at most data points was within $200 \%$ throughout the stretch of the study area (Figure 2), with few points going beyond $500 \%$. The moderate level of supersaturation is also due to a lack of adequate supply of $\mathrm{CO}_{2}$-rich freshwater from rivers as observed in a recent study in the Matla estuary (Akhand et al., $2021 b)$. However, $1,000 \%-1,500 \%$ of $\mathrm{CO}_{2}$ saturation values were recorded at site 27 between 20 and $30 \mathrm{~km}$ (Figure 2) in the early monsoon month. Such high values could be a result of $\mathrm{CO}_{2}$-rich freshwater draining into the system in addition to the advective 

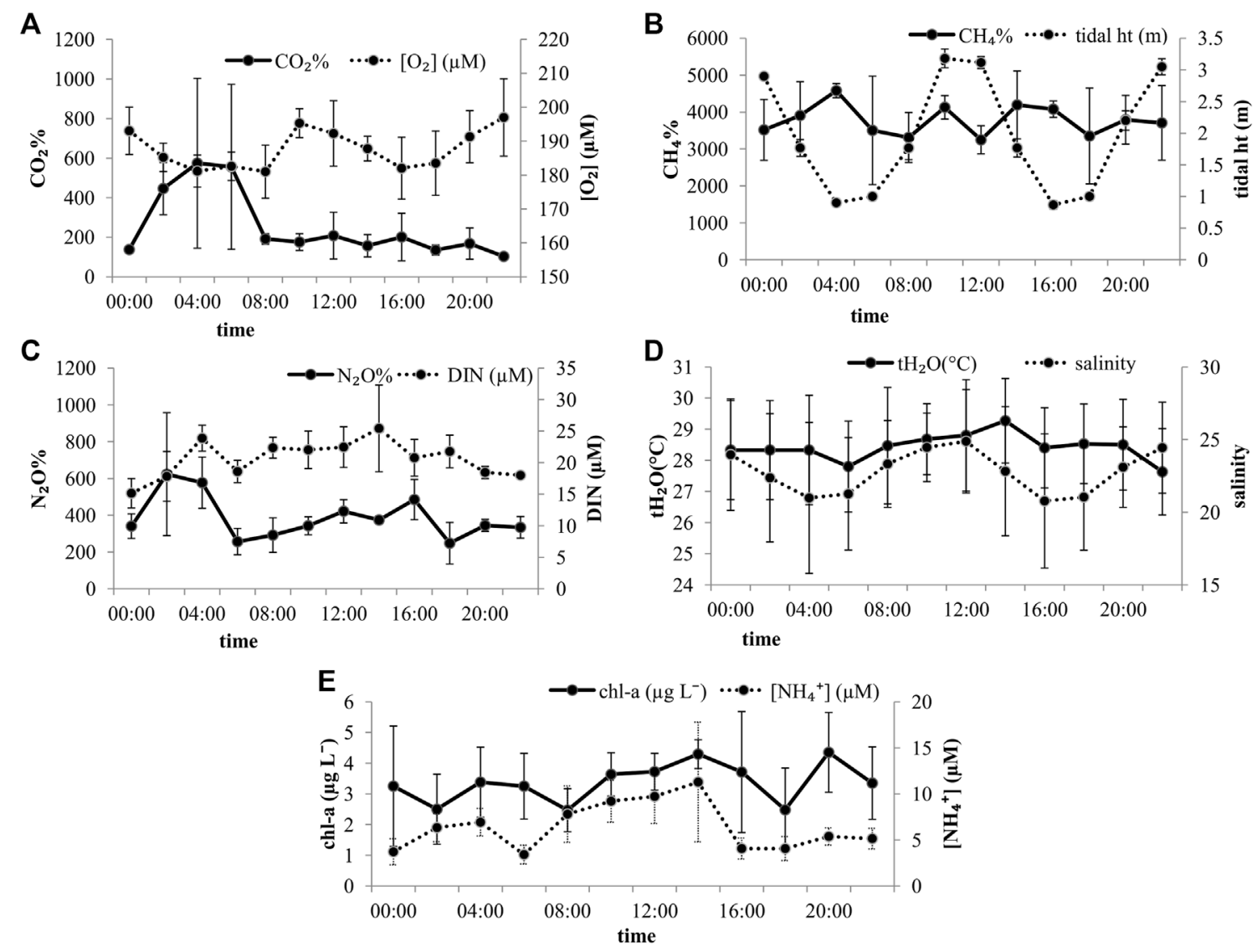

FIGURE 3 | Mean gas saturations and water chemistry across an average of three full tidal cycles at site 27, near Lothian Island in the Indian Sundarban estuary. Error bars equal the standard error of the mean $(n=3)$.

transport of $\mathrm{CO}_{2}$ from the intertidal areas into the adjacent estuary waters.

On the spatial scale, $\mathrm{CO}_{2} \%$ showed a positive correlation with water temperature, salinity, $\mathrm{NO}_{3}{ }^{-}$, and DIC concentrations. $\mathrm{CO}_{2} \%-\mathrm{pH}$ negative correlation is typical of the carbonate system where the $\mathrm{CO}_{2}$ saturation regulates the $\mathrm{pH}$ of the system. The $\mathrm{CO}_{2} \%-\mathrm{O}_{2}$ and $\mathrm{CO}_{2} \%-\mathrm{chl}-a$ correlations are mainly the results of increased turbidity in the estuary waters in the monsoon on receiving adequate organic material from the adjacent intertidal zone to perform microbial degradation. With increased transparency in the estuarine water in the postmonsoon along with the rise in the phytoplankton bio-volume (Biswas et al., 2004), $\mathrm{CO}_{2}$ is consumed during photosynthesis, which explains the low levels of $\mathrm{CO}_{2}$ saturation in the waters in January 2020. The stepwise regression of $\mathrm{CO}_{2} \%$ with the physicochemical parameters narrowed the influencing factors to salinity, $\mathrm{pH}$, and chl- $a$ of the estuary waters, which explained $35 \%$ of the $\mathrm{CO}_{2} \%$ variability $\left(\mathrm{CO}_{2} \%=4,431-6.17\right.$ salinity-499.2 $\left.\mathrm{pH}-19.6 \mathrm{chl}-a ; R^{2}=35.3 \%\right)$.

$\mathrm{CH}_{4}$ and $\mathrm{CO}_{2}$ have been observed to show a positive relationship in well-mixed estuaries, meaning the increase in allochthonous carbon inputs could raise the rates of organic matter decomposition, thus increasing the production of the two gases (Borges and Abril, 2012). A positive correlation between $\mathrm{N}_{2} \mathrm{O} \%$ and $\mathrm{CO}_{2} \%$ in the estuaries implies that the factors that influence the production of these two gases could be common ((Harley et al., 2015). In our study, both $\mathrm{N}_{2} \mathrm{O} \%$ and $\mathrm{CH}_{4} \%$ were positively correlated to $\mathrm{CO}_{2} \%$, suggesting that both the gases were produced via the decomposition of the organic material obtained from advective transport from the intertidal areas adjacent to the estuaries (Sierra et al., 2020). The correlation between $\mathrm{N}_{2} \mathrm{O} \%$ and $\mathrm{CO}_{2} \%$ suggests that denitrification occurring in the intertidal sediments may also be of interest in discussing the dynamics of $\mathrm{N}_{2} \mathrm{O}$ for this system (Harley et al., 2015).

\section{Tidal Pattern}

Only one site in the Saptamukhi, the Lothian Island, was chosen to carry out three tidal observations to assess the tidal pattern of the gases. Several studies have been conducted on this site (Dutta et al., 2019; Ray et al., 2013), considering its position at the confluence of the estuary and the Bay of Bengal and its stable condition that provides a better tidal observation. Comparing the three tidal cycles (Figure 3), it was observed that the approximate tide heights were similar, thus confirming stable tidal variation at the site. The salinity did not show a significant difference between high tide (mean of $23.6 \pm 5.5$ ) and low tide (mean of $22.0 \pm 6.1$ ). 
The mean $\mathrm{N}_{2} \mathrm{O} \%$ varied between 248 and $623 \%$ during the tidal cycles. Considering the average of the three tidal cycles, no clear pattern was observed between the $\mathrm{N}_{2} \mathrm{O}$ saturation values and the salinity of the tidal variation. The values did not vary among tidal cycles as well. Neither light nor tide conditions showed any significant influence on the $\mathrm{N}_{2} \mathrm{O}$ saturation, suggesting that intertidal sediments were not the only contributor to $\mathrm{N}_{2} \mathrm{O} \%$. The average tidal variation of estuarine DIN was well aligned with the average $\mathrm{N}_{2} \mathrm{O}$ tidal variation (Figure $3 \mathrm{C}$ ), further providing an evidence of nitrification. An evidence of microbe-mediated nitrification has been observed in the water column (Mukherjee et al., 2020). Taken together, this means that the in situ $\mathrm{N}_{2} \mathrm{O}$ production occurs within a short time frame and the well-mixed nature of the estuary homogenizes the $\mathrm{N}_{2} \mathrm{O} \%$ in the waters.

Since the observations were carried out only in the early monsoon months, it is not clear what the response of $\mathrm{N}_{2} \mathrm{O}$ might be to tidal variation in the pre-monsoon or postmonsoon months.

In contrast, across the full tidal cycles, high $\mathrm{CH}_{4}$ saturation corresponded to low tide conditions. This indicates that tidal pumping brings in $\mathrm{CH}_{4}$ produced in the sediments to the water column. Similar findings can be cited where, despite no freshwater inputs, the system showed high $\mathrm{CH}_{4}$ concentrations at low tide (Bouillon et al., 2008). Although there was not much statistically significant difference in mean salinity between the high tide salinity and low tide, Figure 3 shows that higher $\mathrm{CH}_{4}$ saturation corresponded with lower salinity at low tide, opposite to what was observed at the spatial scale. The mean $\mathrm{CH}_{4} \%$ varied between 3,249 and 4,582\% considering all three tidal cycles.

$\mathrm{CO}_{2} \%$ too showed a clear tidal variability $(\mathrm{F}=4.72 ; p=0.037)$ (Figure 3). The tidal pattern of $\mathrm{CO}_{2} \%$ varied even with each tidal cycle $(\mathrm{F}=7.49 ; p=0.002)$ with higher saturations at low tide. The mean $\mathrm{CO}_{2} \%$ varied between 103 and 574\%. However, light conditions did not affect its variability. This suggests that the variability of $\mathrm{CO}_{2}$ cannot be detected at the spatial scale but is more prominent at the temporal scale, thus corroborating with the diurnal studies on $\mathrm{CO}_{2}$ dynamics in the Indian Sundarban (Dutta et al., 2019; Akhand et al., 2021). For all three cycles, the increase in $\mathrm{CO}_{2}$ saturation at low tide can be attributed to the advective transport of porewater $\mathrm{CO}_{2}$ in the waters mixing with the estuarine waters. The association of $\mathrm{O}_{2}$ and chl- $a$ with $\mathrm{CO}_{2}$ saturation observed on the spatial scale was not found on the temporal scale. This ambiguity in the $\mathrm{CO}_{2}$-physicochemical parameter relationship further implies that assessing $\mathrm{CO}_{2}$ variability at the temporal scale may prove effective to study its dynamics and biogeochemistry.

\section{Seasonality}

The distribution of the key water parameters, water temperature, salinity, and $\mathrm{O}_{2}$ concentration showed a prominent seasonality (Figure 2). In response to this seasonality, the seasonality index scores of the gas saturations are depicted in Figure 4.

The seasonality index of $\mathrm{N}_{2} \mathrm{O} \%$ was, however, found close to 1 (range: $0.8-1.7$ ). This indicates that the $\mathrm{N}_{2} \mathrm{O}$ dynamics in the Indian Sundarban are not entirely influenced by the seasonality of the environmental variables. Rao and Sarma (2013b) showed that the east coast estuaries have higher $\mathrm{N}_{2} \mathrm{O}$ concentration in the dry

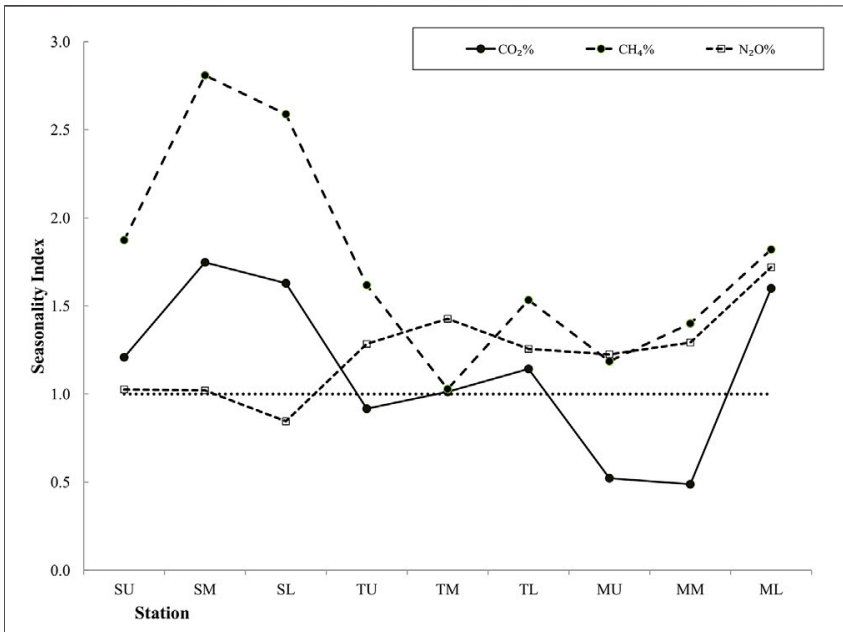

FIGURE 4 | Seasonality index (mean pre-monsoon/early monsoon gas saturation divided by mean late-monsoon/post-monsoon saturations) along the estuary. Study points have been clustered into upper, mid-, and lower regions of the Saptamukhi (SU, SM, SL); Thakuran (TU, TM, TL); and the Matla (MU, MM, ML) for an overview of the seasonality index. Values above a seasonality index of 1 indicate higher pre-monsoon/early monsoon saturations.

period, owing to higher temperatures that enhance the bacterial production of $\mathrm{N}_{2} \mathrm{O}$, while the west coast estuaries did not show any seasonality. Considering most of the significant correlation of $\mathrm{N}_{2} \mathrm{O} \%$ with several physicochemical parameters that occurred in the early monsoon and the late monsoon (Table 1), it can be said that the monsoon season influenced $\mathrm{N}_{2} \mathrm{O}$ saturation in the Indian Sundarban. $\mathrm{N}_{2} \mathrm{O} \%$ was the highest in the early monsoon (mean of $386 \pm 174 \%)$. However, it decreased gradually in the late monsoon (mean of $269 \pm 104 \%$ ) to post-monsoon $(231 \pm 66 \%$ ), possibly with receding freshwater discharge. In the pre-monsoon, $\mathrm{N}_{2} \mathrm{O} \%$ rose to $311 \pm 87 \%$. The increase in saturation in the early monsoon may have been due to advective transport brought in by monsoonal discharge that augmented the water column nitrification. The cause of least mean $\mathrm{N}_{2} \mathrm{O} \%$ in the post-monsoon may be attributed to the negative overall correlation of $\mathrm{O}_{2}$ concentration with $\mathrm{N}_{2} \mathrm{O}$. The rise in $\mathrm{O}_{2}$ concentration to a maximum in the post-monsoon (mean of $240 \mu \mathrm{M}$ ) may have limited $\mathrm{N}_{2} \mathrm{O}$ production in the waters by facilitating its transformation to $\mathrm{NO}_{3}{ }^{-}$instead of nitrification.

For $\mathrm{CH}_{4}$, the seasonality index score was always above 1 , indicating visibly higher pre-monsoon/early monsoon $\mathrm{CH}_{4}$ saturation than its late-monsoon/post-monsoon counterpart for our study. The index score was the highest in the midSaptamukhi region, suggesting significant sources of $\mathrm{CH}_{4}$-rich water from the adjacent mangrove swamps (Biswas et al., 2007) within this region that are most active in the pre-monsoon/early monsoon period. However, previous studies, which also pinpointed the high seasonality of $\mathrm{CH}_{4}$ in the estuaries of the Sundarban mangroves, had observed peak $\mathrm{CH}_{4}$ concentration in the post-monsoon period (Biswas et al., 2007). Those studies attributed this high concentration to methane production from phytoplankton bloom (Biswas et al., 2007). For our study, the 
TABLE 2 | A. Annual emission estimation of air/water RAG emission with global warming potential and B. Seasonal emission estimate of air/water RAG emission integrated from the flux estimates calculated from four different parameterizations of gas transfer rate.

\begin{tabular}{|c|c|c|c|c|c|c|c|}
\hline & & $\begin{array}{c}\mathrm{Gg} \mathrm{CO} \\
\mathrm{y}^{-1}\end{array}$ & GWP & $\begin{array}{c}\mathrm{Gg} \mathrm{CH} \\
\mathrm{y}^{-1}\end{array}$ & GWP & $\mathrm{Gg} \mathrm{N}_{2} \mathrm{O} \mathrm{y}^{-1}$ & GWP \\
\hline \multirow[t]{4}{*}{$A$} & C95 & 368.2 & 368.2 & 0.7 & 18.5 & 0.3 & 88.6 \\
\hline & $\mathrm{RC} 01$ & 573.8 & 573.8 & 1.6 & 45.2 & 0.9 & 230.4 \\
\hline & H11 & 419.2 & 419.2 & 0.8 & 22.5 & 0.5 & 120.0 \\
\hline & W14 & 394.0 & 394.0 & 1.1 & 29.5 & 0.4 & 112.8 \\
\hline \multirow[t]{4}{*}{ B } & PRM & 131 & & 0.682 & & 0.478 & \\
\hline & EM & 721 & & 1.74 & & 0.878 & \\
\hline & LM & 512 & & 0.473 & & 0.213 & \\
\hline & POM & 171 & & 0.29 & & 0.150 & \\
\hline
\end{tabular}

reversal in seasonality can be attributed to the high mean $\mathrm{CH}_{4}$ saturations in June 2019 and August 2019 than other sampling months (Table 1). The reversal could also be due to the positive correlation between chl- $a$ (an indicator of primary productivity) and $\mathrm{CH}_{4} \%$ in the early monsoon season (Table 2). Such a correlation suggests that the conditions were favorable for the phytoplankton to produce $\mathrm{CH}_{4}$ (Biswas et al., 2007). The seasonal dynamics in $\mathrm{CH}_{4} \%$ in the entire estuary can also be justified by the seasonal changes in temperature and $\mathrm{O}_{2}$ concentrations affecting the microbial methanogenesis process in the intertidal sediments since $\mathrm{CH}_{4} \%$ was significantly positively correlated with water temperature and negatively correlated with $\mathrm{O}_{2}$ (Table 1). Similar observations have been found in the Tay Estuary, United Kingdom (Harley et al., 2015).

Although $\mathrm{CO}_{2}$ saturation showed significant seasonality $(\mathrm{F}=$ $6.56, p=0.00$ ), considering the site clusters of the upper, middle, and lower regions in each of the Saptamukhi, Thakuran, and the Matla estuaries, there was no significant difference between the premonsoon/early monsoon and the late-monsoon/post-monsoon saturations as per the $t$-test. This pattern was also observed for the relationships of $\mathrm{CO}_{2}$ saturation with physicochemical parameters (Table 1). In general, $\mathrm{CO}_{2}$ saturation was significantly correlated with several physicochemical parameters like water temperature, oxygen concentration, $\mathrm{pH}, \mathrm{NO}_{3}{ }^{-}, \mathrm{DIN}$, and chlorophyll- $a$ (Table 1). However, the correlations varied between seasons, and most of the correlations became nonexistent beyond early monsoon (Table 1). For instance, the $\mathrm{CO}_{2} \%$-water temperature positive relationship was present in general, but there was no significant relationship in the latemonsoon and post-monsoon season. Similarly, the $\mathrm{CO}_{2} \%-\mathrm{O}_{2}$ negative relationship was significant in general (Table 1) and from the pre-monsoon to the early monsoon. Late monsoon onwards, the relationship lost its significance.

\section{Seasonal Variation of the Advective Transport and Emission of the RAGs From the Intertidal Sediment}

Several studies have already established that the Indian Sundarban estuaries receive organic materials from the adjacent intertidal areas. In this regard, the seasonal variation is regarded as one of the prominent factors influencing RAG emissions from the mangrove swamps (Padhy et al., 2020). In our study, we attempted to estimate the emission of the RAGs from the intertidal areas of the mangrove swamps to relate to the influence of porewater RAGs on the estuary-dissolved RAGs. The advective transport of the porewater-dissolved RAGs from the intertidal sediment to the adjacent waters of the estuaries was estimated to assess their impact on the gas saturation. Figures 5A-C compare the means of the advective transport of the gases for pre-monsoon and monsoon, and Figures 5C-E compare the means of the gas emission from the mangrove sediment for site 27. Only seasonal comparison has been made using the transport rates from all the three estuaries since the transport rates did not vary by estuaries but showed significant seasonal variation.

The advective transport of $\mathrm{N}_{2} \mathrm{O}$ from the intertidal sediment to the estuary water ranged from 0.02 to $0.19 \mu \mathrm{mol} \mathrm{m}^{-2} \mathrm{~h}^{-1}$. The transport increased from pre-monsoon to monsoon (Figure 5A). This is obvious because the monsoon is characterized by substantial inputs of $\mathrm{C}$ - and $\mathrm{N}$-material to the sediments via run-off. This suggests that the porewater $\mathrm{N}_{2} \mathrm{O}$ is an important contributor to the rise in water $\mathrm{N}_{2} \mathrm{O} \%$ in the early monsoon. The emission of $\mathrm{N}_{2} \mathrm{O}$ from the mangrove sediments ranged from -5.02 to $19.2 \mu \mathrm{mol} \mathrm{m}{ }^{-2} \mathrm{~h}^{-1}$, with wider variation than that recorded for other Indian mangroves ;0.38-0.76 $\mu \mathrm{mol} \mathrm{m}^{-2} \mathrm{~h}^{-1}$ in the Muthupet mangroves (Krithika et al., 2008); $0.2-4.3 \mu \mathrm{mol} \mathrm{m}{ }^{-2} \mathrm{~h}^{-1}$ in the Bhitarkanika mangroves (Chauhan et al., 2015)]. Such high variation is probably a direct result of the larger spatial area $\left(\sim 1,800 \mathrm{~km}^{2}\right.$; Dutta et al., 2015) of the Indian Sundarban mangroves than the compared mangroves $\left(68 \mathrm{~km}^{2}\right.$, Muthupet mangroves, Krithika et al., 2008; $670 \mathrm{~km}^{2}$, Bhitarkanika mangroves, Chauhan et al., 2015). Added to the large spatial cover is the entry of substantial amounts of allochthonous inorganic nitrogen from the agricultural fields via rainfall run-off (Ray et al., 2014).

In contrast, the advective transport of $\mathrm{CH}_{4}$ varied by a wide range with no visible influence of seasons. For $\mathrm{CH}_{4}$, the transport rate ranged from 0.27 to $41.48 \mu \mathrm{mol} \mathrm{m} \mathrm{m}^{-2} \mathrm{~h}^{-1}$. Similarly, the variation in sediment $\mathrm{CH}_{4}$ emissions (-51.95-64.14 $\left.\mu \mathrm{mol} \mathrm{m}^{-2} \mathrm{~h}^{-1}\right)$ was too high to pinpoint seasonality (Figure 5E). Since all measurements using the static chamber were conducted at low tide, the effect of tidal fluctuation cannot be discussed here. This aberrant pattern of $\mathrm{CH}_{4}$ emission hints at a complex interaction between the porewater salinity, microbial activity, and advective transport of porewater-dissolved $\mathrm{CH}_{4}$ rather than seasons.

The advective transport of $\mathrm{CO}_{2}$ varied between 0.17 and $2.03 \mathrm{mmol} \mathrm{m}^{-2} \mathrm{~h}^{-1}$. The advective transport of $\mathrm{CO}_{2}$ was found to increase in the monsoon, albeit with a large variation about the mean, whose effects can be seen on the increase in estuary $\mathrm{CO}_{2} \%$ in the monsoon. The $\mathrm{CO}_{2}$-rich porewater seeps out more into the estuary waters in the monsoon and adds to the rainfall run-off. This ultimately increases the mean $\mathrm{CO}_{2} \%$ in the waters. The sediment/air emission of $\mathrm{CO}_{2}$, however, did not show any prominent seasonality for the study period.

RAG Fluxes and Annual Emission Estimates

The gas transfer rates computed by each parameterization varied considerably, with the mean $\mathrm{k}_{600}$ for each parameterization 

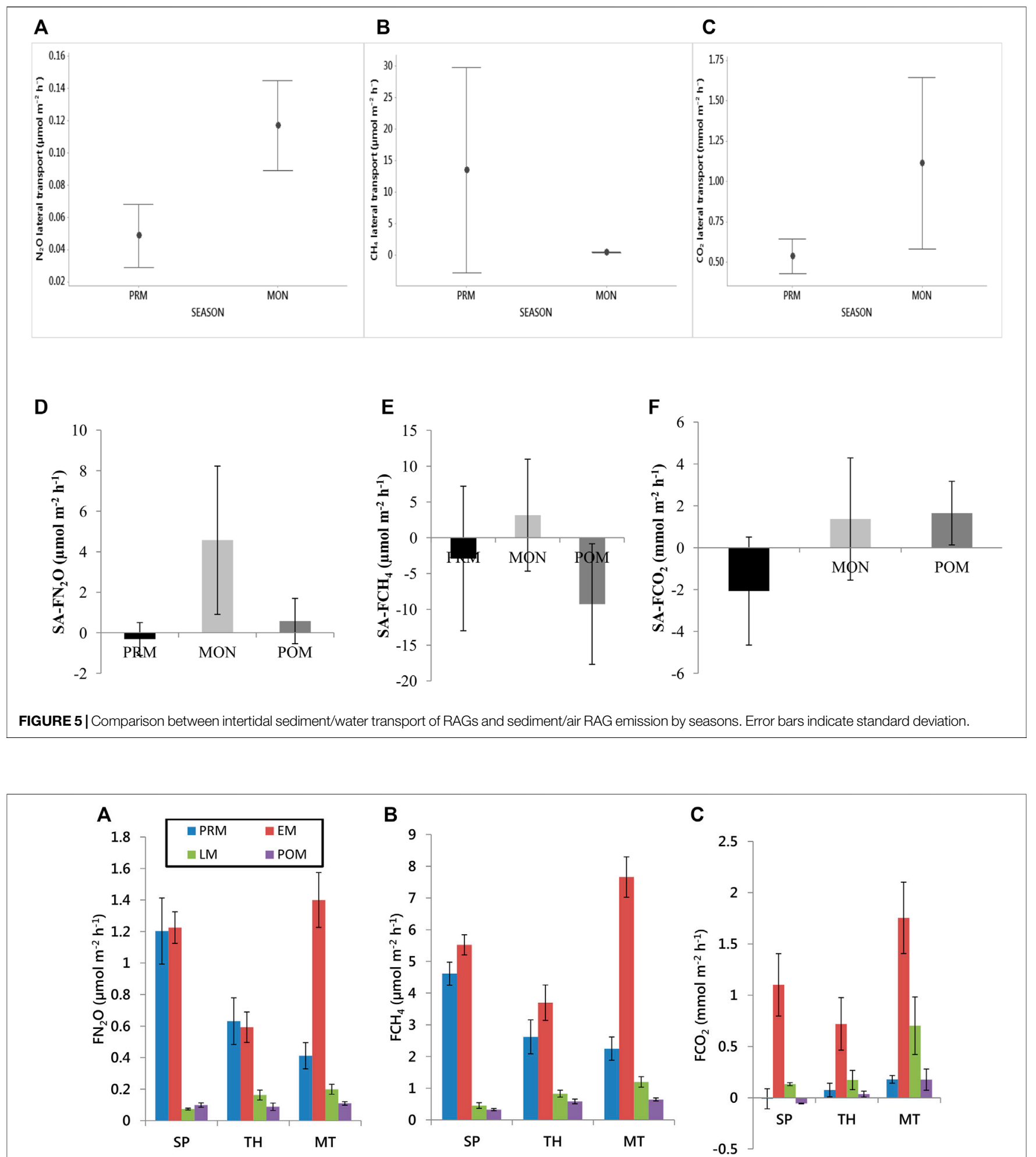

FIGURE 6 | Air/water flux densities in the three estuaries of the Indian Sundarbans (SP-Saptamukhi, TH- Thakuran, and MT- Matla in the pre-monsoon, early monsoon, late monsoon, and the post-monsoon). 
TABLE 3 | Comparative of RAG fluxes of this study with reports from other estuaries.



ranging from 2.76 to $5.00 \mathrm{~cm} \mathrm{~h}^{-1}$, implying the uncertainty involved in using $\mathrm{k}$-wind parameterizations. The uncertainty, is, however, outlined by reporting a range of values (minimum: C95 equation and maximum: RC01 equation).

From Figure 6, it is clear that the air/water flux densities of all the gases were highly variable among the estuaries. The fluxes of the gases in the Thakuran estuary, in general, were less than the other two estuaries. This could be attributed to greater tidal influence and proximity to the marine waters of the Bay of Bengal that dilute the gas concentrations (Chauhan et al., 2015). Seasonally, the flux densities were also the highest in the early monsoon. This could be a response to the enhanced advective transport of the porewater rich in these gases into the water column that may have augmented the estuarine production of the gases.

For $\mathrm{N}_{2} \mathrm{O}$, the fluxes in the late monsoon and post-monsoon dipped considerably. Although the advective transport increased for $\mathrm{N}_{2} \mathrm{O}$ in the monsoon, the oxygenated environment of the waters may have immediately led to its oxidation to $\mathrm{NO}_{3}{ }^{-}$by the blooming phytoplankton for consumption by late monsoon, thus suppressing the water/air fluxes in the subsequent seasons. The minimum flux reached a negative value perhaps due to local consumption of $\mathrm{N}_{2} \mathrm{O}$ via nitrification (Table 3).

A clear seasonality of $\mathrm{CH}_{4}$ fluxes reinforces the dependence of $\mathrm{CH}_{4}$ concentration on water parameters which are, in turn, influenced by seasons (Figure 6B). Our reported range is larger than the previous reports covering only the Saptamukhi and Matla estuaries of the Indian Sundarban (Table 3). All positive flux densities reiterate the previous studies that this estuary is a considerable source of $\mathrm{CH}_{4}$.

The air/water emissions of $\mathrm{CO}_{2}$ fluctuated between negative and positive, similar to $\mathrm{N}_{2} \mathrm{O}$ (Figure $6 \mathrm{C}$ ). The average premonsoon and post-monsoon $\mathrm{CO}_{2}$ fluxes in the Saptamukhi were negative. Since heterotrophy is known to be the lowest in the Indian Sundarban estuaries in the post-monsoon due to bloom conditions (Biswas et al., 2004), this could explain the low flux rates of $\mathrm{CO}_{2}$ in the Saptamukhi estuary. Our study suggests that heterotrophy is suppressed even in the premonsoon despite the advective input of organic matter from the intertidal areas. Combined with the lack of freshwater supply and suppressed heterotrophy in two seasons, inadequate production of $\mathrm{CO}_{2}$ leads to rather low emission rates relative to the amount of organic matter input received by the Sundarban estuary waters (Dutta et al., 2019).

Considering the average of air/water flux densities estimated from the four chosen gas transfer velocity equations, the air/water flux values obtained for our study were extrapolated to the total estuarine area of $1,800 \mathrm{~km}^{2}$ to estimate the annual air/water emission of the gases (Table 2). The estimated annual $\mathrm{N}_{2} \mathrm{O}$ emission ranges from 0.3 to $0.9 \mathrm{Gg} \mathrm{N}_{2} \mathrm{O} \mathrm{y}^{-1}$ corresponding to a GWP of 88.6-230.4. $\mathrm{CH}_{4}$ emission ranges from 0.7 to $1.6 \mathrm{Gg}$ $\mathrm{CH}_{4} \mathrm{y}^{-1}$ corresponding to a GWP of 18.5-45.2, in contrast to $\mathrm{CO}_{2}$ emission that ranges from 368.2 to $573 \mathrm{Gg} \mathrm{CO}_{2} \mathrm{y}^{-1}$ (Table 2). We have not estimated the annual sediment-to-air emission of the RAGs for the whole mangrove intertidal sediment area as estimation using measurements from only one site could lead to gross uncertainty in the estimated emission. With more information on other estuaries available in the future, annual sediment/air emission can become relevant.

Table 3 summarizes a comparative between the RAG air/water fluxes in other estuaries. Compared to other estuaries, the $\mathrm{CO}_{2}$ fluxes in our study were found to vary over a narrower range; $\mathrm{CH}_{4}$ fluxes were within the range of 26 Indian estuaries (Rao and Sarma, 2016), and the $\mathrm{N}_{2} \mathrm{O}$ flux range included the flux values of all other Indian estuaries.

\section{CONCLUSION}

In summary, the distribution of the fluxes of $\mathrm{CO}_{2}, \mathrm{CH}_{4}$, and $\mathrm{N}_{2} \mathrm{O}$ in the Indian Sundarban estuaries had more pronounced seasonal influence, particularly during the early monsoon. While $\mathrm{N}_{2} \mathrm{O}$ may be a product of combined pelagic metabolism and advective transport of porewater, $\mathrm{CH}_{4}$ and $\mathrm{CO}_{2}$ are of sedimentary origin, supplied to the estuary via advective transport. These production and utilization processes that govern the dynamics of their concentration and fluxes require further insight. For water-air fluxes, different estuarine regimes, and their physicochemical and meteorological patterns combined, play a key role. Finally, these water-air $\mathrm{CO}_{2}, \mathrm{CH}_{4}$, and $\mathrm{N}_{2} \mathrm{O}$ flux 
estimates show that the estuaries are a modest source of $\mathrm{CH}_{4}$ but fluctuate between sources and sinks for $\mathrm{CO}_{2}$ and $\mathrm{N}_{2} \mathrm{O}$ gases. The estimates can be used to add to the basic inventories for the database on RAGs of Indian Sundarban. In addition, the revised database will be helpful for the future modeling of $\mathrm{CO}_{2}, \mathrm{CH}_{4}$, and $\mathrm{N}_{2} \mathrm{O}$ budgets for these estuaries.

\section{DATA AVAILABILITY STATEMENT}

The original contributions presented in the study are included in the article, further inquiries can be directed to the corresponding author.

\section{AUTHOR CONTRIBUTIONS}

AA collected the gas samples, carried out the analysis and wrote the manuscript. PS, MP, and SB helped with the measurements of water parameters like salinity, nutrients, VKG helped with the field measurements and datasheet

\section{REFERENCES}

Akhand, A., Chanda, A., Watanabe, K., Das, S., Tokoro, T., Chakraborty, K., et al. (2021). Low CO2 Evasion Rate from the Mangrove-Surrounding Waters of the Sundarbans. Biogeochemistry 153 (1), 95-114. doi:10.1007/s10533-021-00769-9

Akhand, A., Chanda, A., Watanabe, K., Das, S., Tokoro, T., Hazra, S., et al. (2021). Reduction in Riverine Freshwater Supply Changes Inorganic and Organic Carbon Dynamics and Air-Water CO 2 Fluxes in a Tropical Mangrove Dominated Estuary. J. Geophys. Res. Biogeosci 126, 1-22. doi:10.1029/ 2020jg006144

Alongi, D. M. (2012). Carbon Sequestration in Mangrove Forests. Carbon Manag. 3 (3), 313-322. doi: $10.4155 / \mathrm{cmt} .12 .20$

Bange, H. W. (2008, Gaseous Nitrogen Compounds (NO, N2O, N2, NH3) in the Ocean). Chapter 2 - Gaseous Nitrogen Compounds (NO, N2O, N2, NH3) in the Ocean (D. G. Capone, D. A. Bronk, and M. R. Mulholland, \& E. J. B. T.-N. in the M. E.(Second E. Carpenter (eds.); pp. 51-94). Academic Press. doi:10.1016/ B978-0-12-372522-6.00002-5

Bange, H. W., Sim, C. H., Bastian, D., Kallert, J., Kock, A., Mujahid, A., et al. (2019). Nitrous Oxide $(\mathrm{N} 2 \mathrm{O})$ and Methane $(\mathrm{CH} 4)$ in Rivers and Estuaries of Northwestern Borneo. Biogeosciences 16, 4321-4335. doi:10.5194/bg-164321-2019

Barnes, J., and Upstill-Goddard, R. C. (2011). N2O Seasonal Distributions and AirSea Exchange in UK Estuaries: Implications for the Tropospheric N2O Source from European Coastal Waters. J. Geophys. Res. 116 (1). doi:10.1029/ 2009JG001156

Bhattacharyya, P., Nayak, A. K., Mohanty, S., Tripathi, R., Shahid, M., Kumar, A., et al. (2013a). Greenhouse Gas Emission in Relation to Labile Soil C, N Pools and Functional Microbial Diversity as Influenced by 39 Years Long-Term Fertilizer Management in Tropical rice. Soil Tillage Res. 129, 93-105. doi:10. 1016/j.still.2013.01.014

Bhattacharyya, P., Nayak, A. K., Mohanty, S., Tripathi, R., Shahid, M., Kumar, A., et al. (2013b). Greenhouse Gas Emission in Relation to Labile Soil C, N Pools and Functional Microbial Diversity as Influenced by 39 Years Long-Term Fertilizer Management in Tropical rice. Soil Tillage Res. 129, 93-105. doi:10. 1016/j.still.2013.01.014

Bhattacharyya, P., Roy, K. S., Das, M., Ray, S., Balachandar, D., Karthikeyan, S., et al. (2016). Elucidation of rice Rhizosphere Metagenome in Relation to Methane and Nitrogen Metabolism under Elevated Carbon Dioxide and Temperature Using Whole Genome Metagenomic Approach. Sci. Total Environ. 542, 886-898. doi:10.1016/j.scitotenv.2015.10.154 preparation. SKM supervised the entire process from data collection to writing the manuscript.

\section{FUNDING}

West Bengal State Council of Science and Technology Award number: 130/WBSCST/F/0443/13 (Pt-I) dt February 29, 2016 Awarded the Meghnad Saha Research Fellowship in River Science and Research to carry out this research for 4 years.

\section{ACKNOWLEDGMENTS}

The authors are immensely grateful to the Divisional Forest Office, South 24 Parganas for providing permission for field visits to Indian Sundarban. The author AA acknowledges the West Bengal State Council of Science and Technology for providing Meghnad Saha Research Fellowship in River Science and Research to carry out this research and Dr. Pratap Bhattacharyya, NRRI, Cuttack for instrument facilities.

Biswas, H., Mukhopadhyay, S. K., De, T. K., Sen, S., and Jana, T. K. (2004). Biogenic Controls on the Air-Water Carbon Dioxide Exchange in the Sundarban Mangrove Environment, Northeast Coast of Bay of Bengal, India. Limnol. Oceanogr. 49 (1), 95-101. doi:10.4319/lo.2004.49.1.0095

Biswas, H., Mukhopadhyay, S. K., Sen, S., and Jana, T. K. (2007). Spatial and Temporal Patterns of Methane Dynamics in the Tropical Mangrove Dominated Estuary, NE Coast of Bay of Bengal, India. J. Mar. Syst. 68 (1-2), 55-64. doi:10. 1016/j.jmarsys.2006.11.001

Borges, Alberto. V. (2011). Oceans and the Atmospheric Carbon Content. doi:10. 1007/978-90-481-9821-4

Borges, A. V., and Abril, G. (2011). "Carbon Dioxide and Methane Dynamics in Estuaries," in Treatise on Estuarine and Coastal Science, 119-161. doi:10.1016/ B978-0-12-374711-2.00504-0

Bouillon, S., Connolly, R. M., and Lee, S. Y. (2008). Organic Matter Exchange and Cycling in Mangrove Ecosystems: Recent Insights from Stable Isotope Studies. J. Sea Res., 59(1), 44-58. doi:10.1016/j.seares.2007.05.001

Bouillon, S., Frankignoulle, M., Dehairs, F., Velimirov, B., Eiler, A., Abril, G., et al. (2003). Inorganic and Organic Carbon Biogeochemistry in the Gautami Godavari Estuary (Andhra Pradesh, India) during Pre-monsoon: The Local Impact of Extensive Mangrove Forests. Glob. Biogeochem. Cycles 17 (4), a-n. doi:10.1029/2002GB002026

Brase, L., Bange, H. W., Lendt, R., Sanders, T., and Dähnke, K. (2017). High Resolution Measurements of Nitrous Oxide (N2O) in the Elbe Estuary. Front. Mar. Sci. 4 (May). doi:10.3389/fmars.2017.00162

Burgos, M., Sierra, A., Ortega, T., and Forja, J. M. (2015). Anthropogenic Effects on Greenhouse Gas (CH4 and N2O) Emissions in the Guadalete River Estuary (SW Spain). Sci. Total Environ. 503-504, 179-189. doi:10.1016/j.scitotenv.2014. 06.038

Cai, W.-J., and Wang, Y. (1998). The Chemistry, Fluxes, and Sources of Carbon Dioxide in the Estuarine Waters of the Satilla and Altamaha Rivers, Georgia. Limnol. Oceanogr. 43 (4), 657-668. doi:10.4319/lo.1998. 43.4.0657

Chatterjee, M., Shankar, D., Sen, G. K., Sanyal, P., Sundar, D., Michael, G. S., et al. (2013). Tidal Variations in the Sundarbans Estuarine System, India. J. Earth Syst. Sci. 122 (4), 899-933. doi:10.1007/s12040-013-0314-y

Chauhan, R., Datta, A., Ramanathan, A., and Adhya, T. K. (2015). Factors Influencing Spatio-Temporal Variation of Methane and Nitrous Oxide Emission from a Tropical Mangrove of Eastern Coast of India. Atmos. Environ. 107, 95-106. doi:10.1016/j.atmosenv.2015.02.006

Chou, W.-C., Gong, G.-C., Hung, C.-C., and Wu, Y.-H. (2013). Carbonate mineral Saturation States in the East China Sea: Present Conditions and Future 
Scenario. Biogeosciences Discuss. 10 (3), 5555-5590. doi:10.5194/bgd-10-55552013

Clark, J. F., Schlosser, P., Simpson, H. J., Stute, M., Wanninkhof, R., and Ho, D. T. (1995). Relationship between Gas Transfer Velocities and Wind Speeds in the Tidal Hudson River Determined by Dual Tracer Technique. Air-Water Gas Transfer, 785-800. Available at: http://hci.iwr.uni-heidelberg.de/publications/ dip/1995/AWGT1995/CHAPTERS/6_11.PDF.

Collier, S. M., Ruark, M. D., Oates, L. G., Jokela, W. E., and Dell, C. J. (2014). Measurement of Greenhouse Gas Flux from Agricultural Soils Using Static chambers. J. Vis. Exp. 90, e52110. doi:10.3791/52110

Crosswell, J. R., Wetz, M. S., Hales, B., and Paerl, H. W. (2012). Air-water CO2fluxes in the Microtidal Neuse River Estuary, North Carolina. J. Geophys. Res. 117 (8), a-n. doi:10.1029/2012JC007925

Daniel, I., DeGrandpre, M., and Farías, L. (2013). Greenhouse Gas Emissions from the Tubul-Raqui Estuary (central Chile $36^{\circ} \mathrm{S}$ ). Estuarine, Coastal Shelf Sci. 134 (3), 31-44. doi:10.1016/j.ecss.2013.09.019

Das, G. K. (2016). Geomorphic Environments of the Thakuran River of the Sunderbans, India. Earth Sci. India 9 (3). doi:10.31870/esi.09.3.2016.9

Dickson, A. G. (1990). Thermodynamics of the Dissociation of Boric Acid in Synthetic Seawater from 273.15 to 318.15 K. Deep Sea Research Part A. Oceanographic Research Papers, 37 (5), 755-756. doi:10.1016/0198-0149(90) 90004-F

Dutta, M. K., Bianchi, T. S., and Mukhopadhyay, S. K. (2017). Mangrove Methane Biogeochemistry in the Indian Sundarbans: A Proposed Budget. Front. Mar. Sci. 4 (JUN). doi:10.3389/fmars.2017.00187

Dutta, M. K., Chowdhury, C., Jana, T. K., and Mukhopadhyay, S. K. (2013). Dynamics and Exchange Fluxes of Methane in the Estuarine Mangrove Environment of the Sundarbans, NE Coast of India. Atmos. Environ. 77, 631-639. doi:10.1016/j.atmosenv.2013.05.050

Dutta, M. K., Kumar, S., Mukherjee, R., Sharma, N., Acharya, A., Sanyal, P., et al. (2019). Diurnal Carbon Dynamics in a Mangrove-Dominated Tropical Estuary (Sundarbans, India). Estuarine, Coastal Shelf Sci., 229(May), 106426. doi:10. 1016/j.ecss.2019.106426

Dutta, M. K., Mukherjee, R., Jana, T. K., and Mukhopadhyay, S. K. (2015). Biogeochemical Dynamics of Exogenous Methane in an Estuary Associated to a Mangrove Biosphere; the Sundarbans, NE Coast of India. Mar. Chem. 170, 1-10. doi:10.1016/j.marchem.2014.12.006

Dutta, M. K., and Mukhopadhyay, S. K. (20162016). Reviews and Syntheses: Methane Biogeochemistry in Sundarbans Mangrove Ecosystem, NE Coast of India; a Box Modeling Approach. Biogeosciences Discuss. (February), 1-61. doi:10.5194/bg-2016-58

Ferrón, S., Ortega, T., Gómez-Parra, A., and Forja, J. M. (2007a). Seasonal Study of Dissolved CH4, CO2 and N2O in a Shallow Tidal System of the bay of Cádiz (SW Spain). J. Mar. Syst. 66 (1-4), 244-257. doi:10.1016/j.jmarsys.2006.03.021

Ferrón, S., Ortega, T., and Gómez-Parra, A. (2007b). Seasonal Study of Dissolved $\mathrm{CH} 4, \mathrm{CO} 2$, and $\mathrm{N} 2 \mathrm{O}$ in a Shallow Tidal System of the bay of Cádiz (SW Spain). undefined. (n.d.). Elsevier. Available at: https://www.sciencedirect.com/science/ article/pii/S0924796306001886 (Retrieved May 26, 2021).

Forster, G., Upstill-Goddard, R. C., Gist, N., Robinson, C., Uher, G., and Woodward, E. M. S. (2009). Nitrous Oxide and Methane in the Atlantic Ocean between $50^{\circ} \mathrm{N}$ and $52^{\circ} \mathrm{S}$ : Latitudinal Distribution and Sea-To-Air Flux. Deep Sea Res. Part Topical Stud. Oceanography 56 (15), 964-976. doi:10.1016/j.dsr2.2008.12.002

Frankignoulle, M., Abril, G., Borges, A., Bourge, I., Canon, C., Delille, B., et al. (1998). Carbon Dioxide Emission from European Estuaries. Science 282 (October), 434-436. doi:10.1126/science.282.5388.434

Griggs, D. J., and Noguer, M. (2002). Climate Change 2001: The Scientific Basis. Contribution of Working Group I to the Third Assessment Report of the Intergovernmental Panel on Climate Change. wea 57 (8), 267-269. doi:10.1256/ 004316502320517344

Guo, X., Dai, M., Zhai, W., Cai, W.-J., and Chen, B. (2009). CO2flux and Seasonal Variability in a Large Subtropical Estuarine System, the Pearl River Estuary, China. J. Geophys. Res. 114 (December 2008). doi:10.1029/2008JG000905

Harley, J. F., Carvalho, L., Dudley, B., Heal, K. V., Rees, R. M., and Skiba, U. (2015). Spatial and Seasonal Fluxes of the Greenhouse Gases N2O, CO2 and CH4 in a UK Macrotidal Estuary. Estuarine, Coastal Shelf Sci. 153, 62-73. doi:10.1016/j. ecss.2014.12.004
Ho, D. T., Wanninkhof, R., Schlosser, P., Ullman, D. S., Hebert, D., and Sullivan, K. F. (2011). Toward a Universal Relationship between Wind Speed and Gas Exchange: Gas Transfer Velocities Measured with3He/SF6during the Southern Ocean Gas Exchange Experiment. J. Geophys. Res. 116 (7). doi:10.1029/ 2010JC006854

Hoppe, C. J. M., Langer, G., Rokitta, S. D., Wolf-Gladrow, D. A., and Rost, B. (2010). On CO2 Pertubation Experiments: Over-determination of Carbonate Chemistry Reveals Inconsistencies. On $\mathrm{CO}_{2}$ Perturbation Experiments: OverDetermination Carbonate Chem. Reveals Inconsistencies 7 (2), 1707-1726. doi:10.5194/bgd-7-1707-2010

IPCC (2014). "Summary for Policymakers," in Climate Change 2014: Synthesis Report. doi:10.1017/CBO9781107415324Contribution of Working Groups I, II, and III to the Fifth Assessment Report of the Intergovernmental Panel on Climate Change

Ivens, W. P., Tysmans, D. J., Kroeze, C., Löhr, A. J., and van Wijnen, J. (2011). Modeling Global N2O Emissions from Aquatic Systems. Curr. Opin. Environ. Sustainability 3 (5), 350-358. doi:10.1016/j.cosust.2011.07.007

Kahmark, K., and Millar, N. (2020). Static Chamber Method for Measuring Soil Greenhouse Gas Fluxes. Hickory Corners, MI: KBS LTER Special Publication. doi:10.5281/zenodo.3629774

Khalil, M. A. K., Rasmussen, R. A., and Shearer, M. J. (2002). Atmospheric Nitrous Oxide: Patterns of Global Change during Recent Decades and Centuries. Chemosphere, 47(8), 807-821. doi:10.1016/S0045-6535(01)00297-1

Krithika, K., Purvaja, R., and Ramesh, R. (2008). Fluxes of Methane and Nitrous Oxide from an Indian Mangrove. Curr. Sci. 94 (2), 218-224.

Laruelle, G. G., Dürr, H. H., Lauerwald, R., Hartmann, J., Slomp, C. P., Goossens, N., et al. (2013). Global Multi-Scale Segmentation of continental and Coastal Waters from the Watersheds to the continental Margins. Hydrol. Earth Syst. Sci. 17 (5), 2029-2051. doi:10.5194/hess-17-2029-2013

Lin, H., Dai, M., Kao, S.-J., Wang, L., Roberts, E., Yang, J.-Y. T., et al. (2016). Spatiotemporal Variability of Nitrous Oxide in a Large Eutrophic Estuarine System: The Pearl River Estuary, China. Mar. Chem. 182, 14-24. doi:10.1016/j. marchem.2016.03.005

Middelburg, J. J., Klaver, G., Nieuwenhuize, J., and Vlug, T. (2000). Carbon and Nitrogen Cycling in Intertidal Sediments Near Doel. Scheldt Estuary 311, 57-69. doi:10.1007/bf00008571

Mukherjee, R., Acharya, A., Gupta, V. K., Bakshi, S., Paul, M., Sanyal, P., et al. (2020). Diurnal Variation of Abundance of Bacterioplankton and High and Low Nucleic Acid Cells in a Mangrove Dominated Estuary of Indian Sundarbans. Continental Shelf Res. 210, 104256. doi:10.1016/j.csr.2020.104256

Mukhopadhyay, S. K., Biswas, H., De, T. K., and Jana, T. K. (2006). Fluxes of Nutrients from the Tropical River Hooghly at the Land-Ocean Boundary of Sundarbans, NE Coast of Bay of Bengal, India. J. Mar. Syst. 62 (1-2), 9-21. doi:10.1016/j.jmarsys.2006.03.004

Mukhopadhyay, S. K., Biswas, H., De, T. K., Sen, S., and Jana, T. K. (2002). Seasonal Effects on the Air-Water Carbon Dioxide Exchange in the Hooghly Estuary, NE Coast of Bay of Bengal, India. J. Environ. Monit. 4 (4), 549-552. doi:10.1039/ B201614A

Murray, R. H., Erler, D. V., and Eyre, B. D. (2015). Nitrous Oxide Fluxes in Estuarine Environments: Response to Global Change. Glob. Change Biol. 21, 3219-3245. doi:10.1111/gcb.12923

Musenze, R. S., Werner, U., Grinham, A., Udy, J., and Yuan, Z. (2014). Methane and Nitrous Oxide Emissions from a Subtropical Estuary (The Brisbane River Estuary, Australia). Sci. Total Environ. 472, 719-729. doi:10.1016/j.scitotenv.2013.11.085

Naqvi, S. W. A., and Noronha, R. J. (1991). Nitrous oxide in the Arabian Sea. Deep Sea Research Part A. Oceanographic Research Papers, 38 (7), 871-890. doi:10. 1016/0198-0149(91)90023-9

Noronha, R. J. (1991). Nitrous Oxide in the Arabian Sea December 1988. in Water Samples Were Collected Usually Covering the Entire Water Column, 38.7

Orr, J. C., Epitalon, J.-M., Dickson, A. G., and Gattuso, J.-P. (2018). Routine Uncertainty Propagation for the marine Carbon Dioxide System. Mar. Chem. 207, 84-107. doi:10.1016/j.marchem.2018.10.006

Padhy, S. R., Bhattacharyya, P., Dash, P. K., Reddy, C. S., Chakraborty, A., and Pathak, H. (1991). Seasonal Fluctuation in Three Mode of Greenhouse Gases Emission in Relation to Soil Labile Carbon Pools in Degraded Mangrove, Sundarban, India. Science of the Total Environment 705, 135909. doi:10.1016/j. scitotenv.2019.135909 
Parsons, T. R., Maita, Y., and Lalli, C. M. (1984). A Manual of Chemical and Biological Methods for Seawater Analysis. Pergamon Press.

Rao, G. D., and Sarma, V. V. S. S. (2016). Variability in Concentrations and Fluxes of Methane in the Indian Estuaries. 39 (6), 1-23.doi:10.1007/s12237-016-0112-2

Rao, G. D., Rao, V. D., and Sarma, V. V. S. S. (2013a). Distribution and Air-Sea Exchange of Nitrous Oxide in the Coastal Bay of Bengal during Peak Discharge Period (Southwest Monsoon). Mar. Chem. 155, 1-9. doi:10.1016/j.marchem.2013.04.014

Rao, G. D., and Sarma, V. V. S. S. (2013b). Contribution of N2O Emissions to the Atmosphere from Indian Monsoonal Estuaries. Tellus B: Chem. Phys. Meteorology 65 (1), 1-9. doi:10.3402/tellusb.v65i0.19660

Ray, R., Chowdhury, C., Majumder, N., Dutta, M. K., Mukhopadhyay, S. K., and Jana, T. K. (2013). Improved Model Calculation of Atmospheric CO2 Increment in Affecting Carbon Stock of Tropical Mangrove forest. Tellus B: Chem. Phys. Meteorology 65 (1), 18981-19011. doi:10.3402/tellusb.v65i0.18981

Ray, R., Majumder, N., Das, S., Chowdhury, C., and Jana, T. K. (2014). Biogeochemical Cycle of Nitrogen in a Tropical Mangrove Ecosystem, East Coast of India. Mar. Chem. 167, 33-43. doi:10.1016/j.marchem.2014.04.007

Raymond, P. A., and Cole, J. J. (2001). Gas Exchange in Rivers and Estuaries: Choosing a Gas Transfer Velocity. Estuaries 24, 312. Gas Exchange in Rivers and Estuaries : Choosing a Gas Transfer. April. doi:10.2307/1352954

Sanyal, P., Ray, R., Paul, M., Gupta, V. K., Acharya, A., Bakshi, S., et al. (2020). Assessing the Dynamics of Dissolved Organic Matter (DOM) in the Coastal Environments Dominated by Mangroves, Indian Sundarbans. Front. Earth Sci. 8 (July), 1-21. doi:10.3389/feart.2020.00218

Seitzinger, S. P., and Kroeze, C. (1998). Global Distribution of Nitrous Oxide Production and N Inputs in Freshwater and Coastal marine Ecosystems. Glob. Biogeochem. Cycles 12 (1), 93-113. doi:10.1029/97GB03657

Sierra, A., Jiménez-López, D., Ortega, T., Gómez-Parra, A., and Forja, J. (2020). Factors Controlling the Variability and Emissions of Greenhouse Gases (CO2, $\mathrm{CH} 4$ and N2O) in Three Estuaries of the Southern Iberian Atlantic Basin during July 2017. Mar. Chem. 226 (July), 103867. doi:10.1016/j.marchem.2020.103867

Simon, J. L. (1997). Resampling: The New Statistics. Cardiovasc. Res. 80 (October), 321-323. Available at: http://www.resample.com/content/text/index.shtml.
Wangersky, P. J. (1978). Methods of Seawater Analysis, Issue 1, Marine Chemistry, 7. doi:10.1016/0304-4203(78)90045-2

Wanninkhof, R. (2014). Relationship between Wind Speed and Gas Exchange over the Ocean Revisited. Limnol. Oceanogr. Methods 12 (JUN), 351-362. doi:10. 4319/lom.2014.12.351

Weiss, R. F., and Price, B. A. (1980). Nitrous Oxide Solubility in Water and Seawater. Mar. Chem. 8 (4), 347-359. doi:10.1016/0304-4203(80)90024-9

Whalen, S. C. (2005). Biogeochemistry of Methane Exchange between Natural Wetlands and the Atmosphere. Environ. Eng. Sci. 22 (Issue 1), 73-94. doi:10. 1089/ees.2005.22.73

Wiesenburg, D. A., and Guinasso, N. L., Jr (1979). Equilibrium Solubilities of Methane, Carbon Monoxide, and Hydrogen in Water and Sea Water. J. Chem. Eng. Data 24 (4), 356-360. doi:10.1021/je60083a006

Wuebbles, D. J., and Hayhoe, K. (2002). Atmospheric Methane and Global Change. Earth-Science Rev., 57(3), 177-210. doi:10.1016/S0012-8252(01)00062-9

Conflict of Interest: The authors declare that the research was conducted in the absence of any commercial or financial relationships that could be construed as a potential conflict of interest.

Publisher's Note: All claims expressed in this article are solely those of the authors and do not necessarily represent those of their affiliated organizations, or those of the publisher, the editors and the reviewers. Any product that may be evaluated in this article, or claim that may be made by its manufacturer, is not guaranteed or endorsed by the publisher.

Copyright (c) 2022 Acharya, Sanyal, Paul, Gupta, Bakshi and Mukhopadhyay. This is an open-access article distributed under the terms of the Creative Commons Attribution License (CC BY). The use, distribution or reproduction in other forums is permitted, provided the original author(s) and the copyright owner(s) are credited and that the original publication in this journal is cited, in accordance with accepted academic practice. No use, distribution or reproduction is permitted which does not comply with these terms. 